QA: QA

TDR-MGR-GE-000005 REV 00

July 2003

\title{
Data Qualification and Data Summary Report: Intact Rock Properties Data on Tensile Strength, Schmidt Hammer Rebound Hardness, and Rock Triaxial Creep
}

\author{
By \\ E. M. Cikanek \\ R. J. Blakely \\ T. A. Grant \\ L. E. Safley
}

Prepared for:

U.S. Department of Energy

Office of Civilian Radioactive Waste Management

Office of Repository Design

P.O. Box 364629

North Las Vegas, Nevada 89036-8629

Prepared by:

Bechtel - SAIC Company, LLC

1180 Town Center Drive

Las Vegas, Nevada 89144

Under Contract Number

DE-AC08-01RW12101 


\section{DISCLAIMER}

This report was prepared as an account of work sponsored by an agency of the United States Government. Neither the United States Government nor any agency thereof, nor any of their employees, nor any of their contractors, subcontractors or their employees, makes any warranty, express or implied, or assumes any legal liability or responsibility for the accuracy, completeness, or any third party's use or the results of such use of any information, apparatus, product, or process disclosed, or represents that its use would not infringe privately owned rights. Reference herein to any specific commercial product, process, or service by trade name, trademark, manufacturer, or otherwise, does not necessarily constitute or imply its endorsement, recommendation, or favoring by the United States Government or any agency thereof or its contractors or subcontractors. The views and opinions of authors expressed herein do not necessarily state or reflect those of the United States Government or any agency thereof. 
Data Qualification and Data Summary Report: Intact Rock Properties Data on Tensile Strength, Schmidt Hammer Rebound Hardness, and Rock Triaxial Creep

Prepared by:
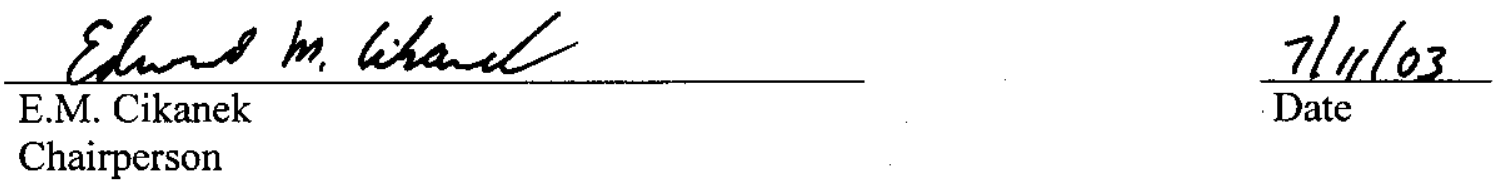

Checked by:

this E, Mohr

D.E. Mohr

Parameter Qualification

Compliance Review by:

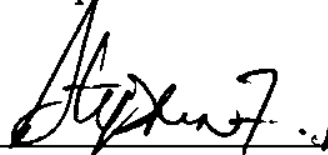

Stephen F. Schuermann

Quality Engineering Representative

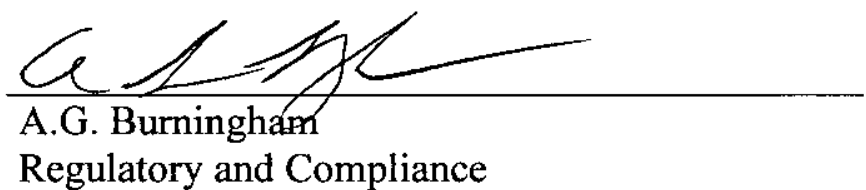

Approved by:

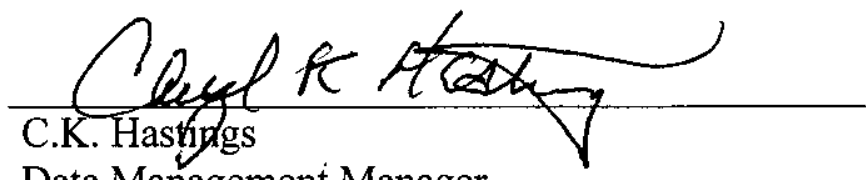

Data Management Manager

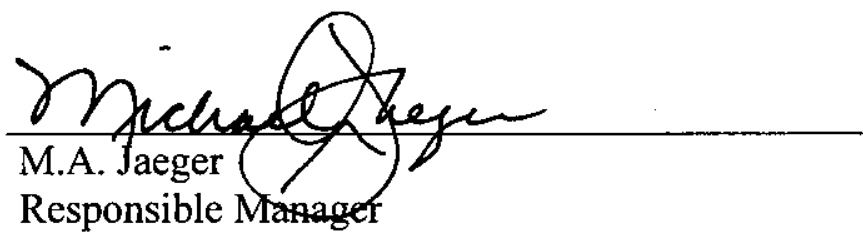

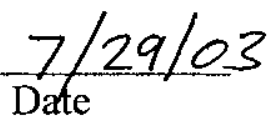

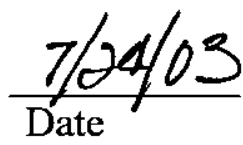

$\frac{7 / 29 / 03}{\text { Date }}$ 


\section{INTENTIONALLY LEFT BLANK}




\section{EXECUTIVE SUMMARY}

An identification, review, and disposition was made of all potentially relevant Data Tracking Numbers (DTNs) that contained data related to tensile strength. Those DTNs that were identified as relevant in this activity and that required verification in accordance with AP-3.15Q, Managing Technical Product Inputs, were verified. One DTN was identified as relevant and unqualified and was included in the data requiring qualification or disposition in accordance with AP-SIII.2Q, Qualification of Unqualified Data. The report summarizes the test results presented in DTN: MO0306DQRIRPTS.002 by providing summary values using descriptive statistics in Table 5. The unqualified data in Table 6 (DTN: MO0301SETSTTST.000) will remain unqualified as a result of the evaluation in this report and will not be included in DTN: MO0306DQRIRPTS.002.

An identification, review, and disposition of all potentially relevant DTNs that contained data related to Schmidt hammer rebound hardness was made. Those DTNs that were identified as relevant in this activity, and that required verification in accordance with $\mathrm{AP}-3.15 \mathrm{Q}$, were verified as qualified. The report summarizes the test results presented in DTN: MO0306DQRIRPSH.001 by providing summary values using descriptive statistics in Table 7.

An identification, review, and disposition of all potentially relevant DTNs that contained data related to rock triaxial creep was made. Those DTNs that were identified as relevant in this activity, and that required verification in accordance with AP-3.15Q, were verified as qualified. Unqualified data from one report and not currently in the Technical Data Management System (TDMS) was included in data requiring qualification or disposition in accordance with APSIII.2Q. The report summarizes the test results presented in DTN MO0306DQRIRPTC.001 by providing summary values using descriptive statistics in Table 8 and Table 9. The unqualified data will remain unqualified as a result of the evaluation in this report and will not be included in summary DTN: MO0306DQRIRPTC.001. 
INTENTIONALLY LEFT BLANK 


\section{CONTENTS}

PAGE

EXECUTIVE SUMMARY V

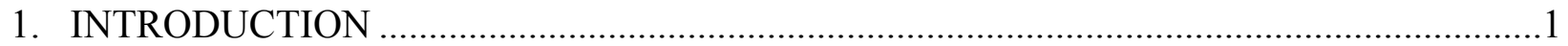

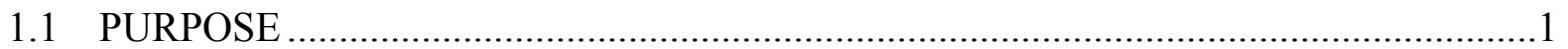

1.2 SCOPE …

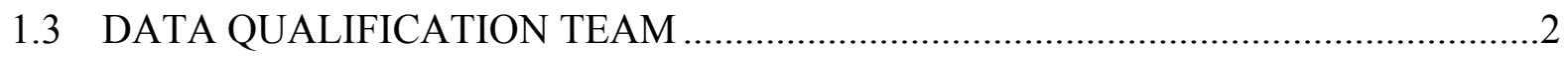

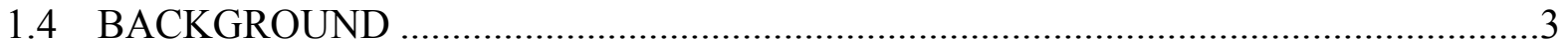

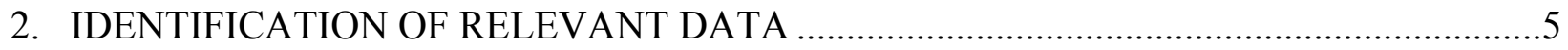

2.1 DATA TRACKING NUMBERS REVIEWED.............................................................

2.2 DATA TRACKING NUMBERS IDENTIFIED AS RELEVANT ...................................6

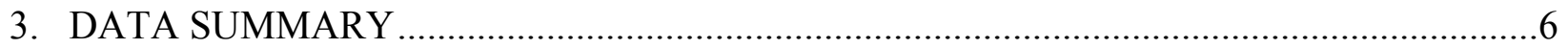

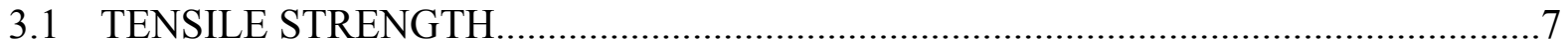

3.2 SCHMIDT HAMMER REBOUND HARDNESS …………...................................

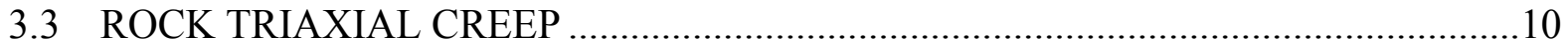

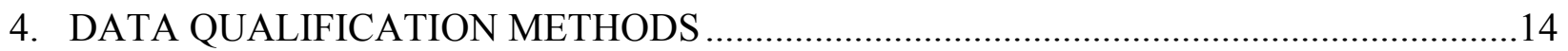

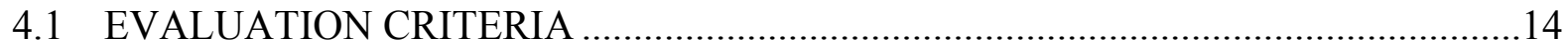

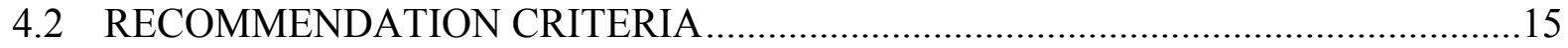

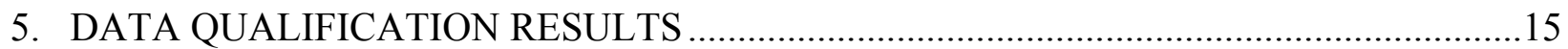

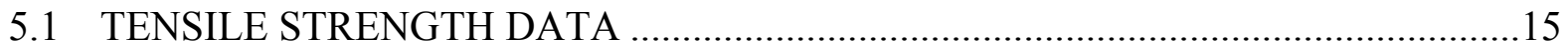

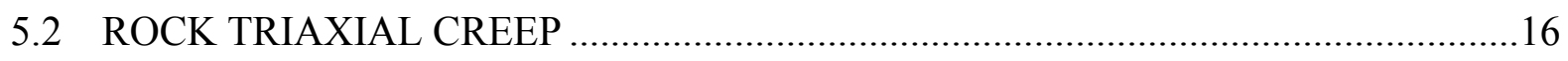

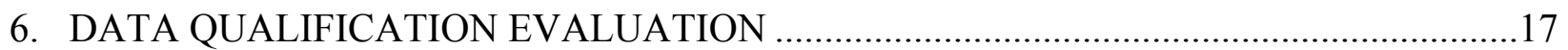

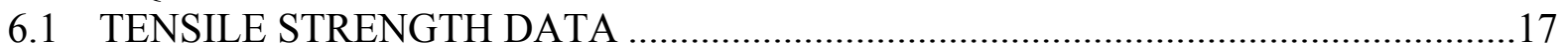

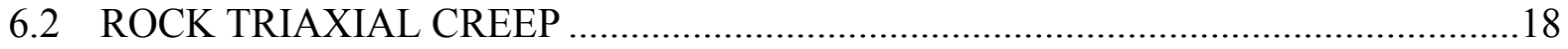

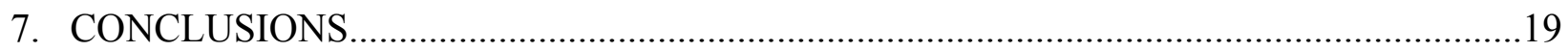

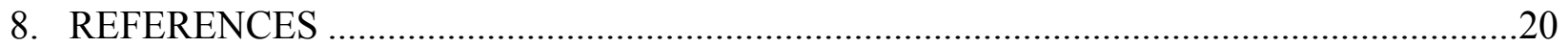

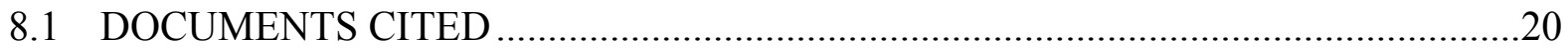

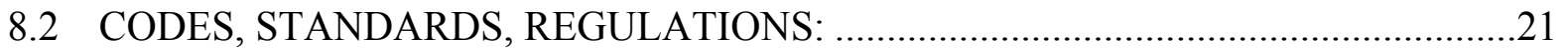

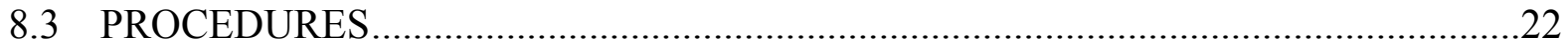

8.4 SOURCE DATA, LISTED BY DATA TRACKING NUMBER ……………...............22

8.5 OUTPUT DATA, LISTED BY DATA TRACKING NUMBER …...............................28

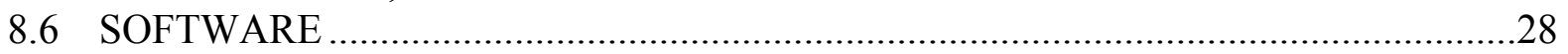

ATTACHMENT I STRATIGRAPHIC COLUMN AND SYMBOLS USED IN REPORT ......I-1 


\section{TABLES}

Page

1. Disposition of DTNs Found Linked to Potentially Relevant Parameters ......................... 29

2. DTNs That Required Verification in Accordance With AP-3.15Q at Start of the

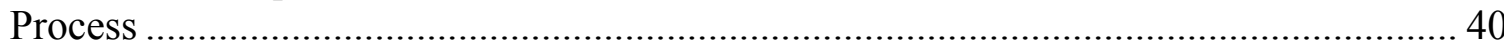

3. DTNs/Reports Whose Data Will Be Reviewed for Qualification in Accordance With AP-SIII.2Q for Use in the Data Summary DTNs

4. DTNs That Will Supply Qualified and Verified Data for the Data Summary DTNs

5. Summary of Qualified Test Results for Brazil Tensile Strength Data by Lithostratigraphic Unit

6. Summary of Test Results for Unqualified Tensile Strength Data by Lithostratigraphic Unit

7. Summary of Test Results for Schmidt Hammer Rebound Hardness Values by Lithostratigraphic Unit

8. Summary of Test Results for Seismic Velocity Values Measured for Creep Calculations

9. Summary of Test Results for Maximum Axial Strain Calculated for Creep Calculations

10. Available Documentation for Unqualified Sources 45

I-1. Stratigraphic Column and Symbols Used in Report $\mathrm{I}-3$ 


\section{ACRONYMS, ABBREVIATIONS, SYMBOLS, AND UNITS}

\section{ACRONYMS AND ABBREVIATIONS}

$\begin{array}{ll}\text { ASTM } & \text { American Society for Testing and Materials } \\ \text { DTN } & \text { Data Tracking Number } \\ \text { QA } & \text { Quality Assurance } \\ \text { RIB } & \text { Reference Information Base } \\ \text { SNL } & \text { Sandia National Laboratories } \\ \text { NER } & \text { New England Research, Inc. } \\ \text { TDMS } & \text { Technical Data Management System } \\ \text { YMP } & \text { Yucca Mountain Project } \\ \text { SYMBOLS AND UNITS } \\ { }^{\circ} \mathrm{C} & \text { degrees Celsius } \\ \text { cm } & \text { centimeter } \\ \text { mm } & \text { millimeter } \\ \text { MPa } & \text { megaPascals } \\ \text { psi } & \text { pounds per square inch } \\ \text { s } & \text { seconds }\end{array}$


INTENTIONALLY LEFT BLANK 


\section{INTRODUCTION}

\subsection{PURPOSE}

This report presents a systematic review of the available data in the TDMS that are relevant to the following intact rock properties: rock tensile strength, Schmidt hammer rebound hardness, and rock triaxial creep. Relevant data are compiled from qualified and unqualified sources into the summary DTNs and these DTNs are evaluated for qualification using the method of corroborating data as defined in AP-SIII.2Q, Qualification of Unqualified Data. This report also presents a summary of the compiled information in the form of descriptive statistics and recommended values that will be contained in a Reference Information Base (RIB) item prepared in accordance with AP-SIII.4Q, Development, Review, Online Placement, and Maintenance of Individual Reference Information Base Data Items.

The primary purpose of this report is to produce qualified sets of data that include all relevant intact rock tensile strength, Schmidt hammer rebound hardness, and rock triaxial creep testing done over the course of the Yucca Mountain Project (YMP). A second purpose is to provide a qualified summary (i.e., a RIB data item) of the test results using descriptive statistics. The immediate purpose of the report is to support the data needs of repository design; however, the products are designed to be appropriate for general use by the YMP. The appropriateness and limitations, if any, of the data, with respect to the intended use, are addressed in this report.

\subsection{SCOPE}

Activities documented in this technical product are quality affecting activities. This report and associated activities have been prepared subject to the requirements of the Quality Assurance Requirements and Description document (DOE 2003) and implementing procedures. This document was developed, checked, and reviewed in accordance with AP-3.11Q, Technical Reports; and was prepared in accordance with the Technical Work Plan for Qualification of Intact Rock Properties Data on Tensile Strength, Schmidt Hammer Rebound Hardness and Rock Triaxial Creep (Cikanek et al., 2003). The technical work plan includes the following major activities and products that are documented in this report:

- An identification, review, and disposition of all potentially relevant DTNs that contain data related to the intact rock properties under consideration was performed. Data related to the following parameters were reviewed and dispositioned: Rock Tensile Strength (Brazilian Method), Rock Tensile Strength (Direct Pull), Schmidt Hammer Rebound Hardness, and Rock Triaxial Creep.

- Data from DTNs identified as containing relevant information were compiled into a single dataset and, upon approval of this report, a new DTN will be created for the summary dataset for each rock property. The data in the summary DTN will be verified or qualified as necessary. Those DTNs that were identified as relevant in the first activity, and that require verification using AP-3.15Q, Managing Technical Product Inputs, will be verified. If adequate documentation was not found to complete the verification process for a particular DTN, the relevant data from that DTN were reviewed as part of the qualification process. 
- Data from those DTNs that were identified as relevant in the first activity and that are unqualified have been included in the data to be qualified in accordance with AP-SIII.2Q. Data that could not be qualified or were determined as not requiring qualification were dispositioned and the impact of unqualified data evaluated in this report.

- Data from those DTNs verified as qualified were directly used in compiling the data summary DTNs.

- This report summarizes the data listed in the new summary data DTNs through the use of descriptive statistics. Data gathered under different environmental conditions (e.g., temperature, saturation) were appropriately segregated in this report.

- The final activity will be the preparation of RIB items based on this report and the data summary DTNs. The RIB items will be prepared in accordance with AP-SIII.4Q.

This report summarizes available data and is therefore prepared under the requirements of AP-3.11Q, while it also responds to the reporting requirements contained in AP-SIII.2Q. No assumptions were made prior to the data identification or during the data disposition, evaluation, and qualification. Only YMP standard software (WORD and EXCEL) were used to generate the information and provide statistical summaries of the data contained in this technical report.

\subsection{DATA QUALIFICATION TEAM}

The Data Qualification Team consisted of the following members:

The Responsible Manager for the data qualification task was Michael A. Jaeger.

\section{Chairperson:}

Mr. Edward M. Cikanek was designated the Chairperson for this Data Qualification Team. Mr. Cikanek is a subject matter expert in the field of geotechnical engineering and the design of underground structures. He has an M.S. degree in civil engineering from the University of Notre Dame (1966) and a B.S. degree in civil engineering from Northwestern University (1964). He has over 35 years of experience in performing design and engineering services for the construction of foundations, embankments, and underground structures. As the lead engineer and group leader for geotechnical departments involved in tunneling projects, he has an extensive background in the collection and use of geotechnical data for tunneling projects. Mr. Cikanek has had no involvement with the collection or processing of the YMP data being qualified.

Technical Representatives:

Mr. Robert Blakely was a Data Qualification Team member. He has a B.S. degree in mining engineering from Montana College of Mineral Science and Technology (1978). He has sixteen years of experience in mine planning, mine operations, tunnel operations, operations management, geological and geophysical investigations, and engineering. He has worked in mine planning for operating mines, in mine operations in Arizona, and in tunnel operations at the 
Nevada Test Site. Mr. Blakely has had no involvement with the collection or processing of the YMP data being qualified.

Mr. Terry Grant was a Data Qualification Team member. He has an M.S. degree (1974) in geology from the University of Nevada, Reno, and a B.S. degree (1968) in geology from UCLA. Mr. Grant is an engineering geologist with experience in site studies and the management of large multidisciplinary projects. He has been responsible for conceiving site selection methodologies and for implementing data gathering studies for high-level nuclear waste repositories and nuclear power plants requiring quality assurance (QA) programs. He has a broad background in data gathering activities of this type and is familiar with the documentation related to the DTN being reviewed. Mr. Grant has had no involvement with the collection or processing of the YMP data being qualified.

Mr. Leslie Eugene Safley is a Data Qualification Team member. He has an M.S. degree (1989) and a B.S. degree (1981) in Geology from Oregon State University, and an MBA degree (1998) from Oklahoma State University. He has a broad background in stratigraphy, hydrogeology, and geophysical data collection and analysis. He has worked on the YMP as a technical report writer and a database administrator of geological and engineering data. Previously, he worked as a project geologist responsible for developing reservoir management plans at the U.S. Department of Energy's National Institute of Petroleum and Energy Research. Mr. Safley has had no involvement with the collection or processing of the YMP data being qualified.

\subsection{BACKGROUND}

The process of underground excavation design is being performed in several phases to satisfy increasingly focused requirements as the YMP progresses and more detailed site characterization data are acquired. Most of the data in this report were obtained from core obtained from vertical boreholes drilled at designated locations. The rock core data represent characteristics of the rock at that particular location.

Commonly, the rock property data are displayed in terms of the mean parameter value and the standard deviation associated with the number of samples used to determine that parameter. The observed scatter of values reflects both the intrinsic variability of rock properties and the impact of the sampling and specimen preparation techniques and testing conditions. The sampling procedure used in the selection of test specimens, or the frequency of observations, reflect the purpose for which the particular parameter is being measured. The scatter is often used to estimate the upper and lower bound for the value of the particular parameter.

The following are simple definitions for the parameters considered in this report:

- Tensile strength is the ability of a material to resist a stress tending to stretch it or to pull it apart.

- Schmidt hammer rebound hardness is a simple portable method of determining the hardness of a material by pushing a spring-loaded plunger against a material.

- The amount of recoil is a measure of the hardness, which can be correlated to strength. 
- Rock triaxial creep is the time-dependent deformation due to constant sustained load.

An integral part of the licensing procedure for the proposed nuclear waste repository at Yucca Mountain, Nevada, involves prediction of the in situ geology for the design and construction of the facility and the emplacement of canisters containing radioactive waste. The data used to model the thermal and mechanical behavior of the repository and surrounding environment includes the tensile strength as an important mechanical property for these design calculations.

Tensile strength was obtained by the direct-pull tensile test and by the Brazil test method. Samples for the direct-pull tension tests were taken from drill cores that were cut and machined to specified right circular cylinders. The samples were glued to tension-loading fixtures that were bolted to the test apparatus loading platens. The upper fixture has a universal joint, which allows the sample to be aligned vertically and parallel with the axis of the load frame. Samples were failed in tension under dry, room temperature constant displacement rate $\left(10^{-5} \mathrm{~mm} \mathrm{~s}^{-1}\right)$ conditions.

The splitting tensile test, or Brazil test, is a desirable alternative to direct-pull tests because it is much simpler and much less expensive. The Brazil test is a standard, routine test for indirectly determining tensile strength. Samples for the Brazil tests were taken from drill cores. The samples were tested following the methods described by Mellor and Hawkes (1971) or ASTM D 3967-86. Both methods are comparable in the design of the test apparatus and in data reduction. In this test, short rock cylinders are machined from the core and compressed between two parallel platens that are oriented parallel to the axis of the cylinder. The platens extend for the full length of the sample cylinder. The loading causes a tensile stress to develop along a diameter of the cylinder. The specimen then fails by an extension fracture along the diametral loading plane. Samples were failed under saturated or room-dry conditions, room temperature, and a constant displacement rate $\left(10^{-5} \mathrm{~mm} \mathrm{~s}^{-1}\right)$. Indirect tensile strength is calculated using the following standard equation (Mellor and Hawkes 1971, p. 225 and ASTM D 3967-86):

$$
\sigma=2 \mathrm{P} /(\pi \mathrm{LD})
$$

Where:

$$
\begin{aligned}
& \sigma=\text { indirect tensile strength or splitting tensile strength, psi } \\
& \mathrm{P}=\text { maximum applied load indicated by the testing machine, pounds force } \\
& \mathrm{L}=\text { sample length, inches } \\
& \mathrm{D}=\text { sample diameter, inches }
\end{aligned}
$$

The Schmidt hammer was originally developed as a simple field test to determine the surface hardness of concrete. Prior to each testing sequence, the Schmidt hammer should be calibrated using a calibration test anvil supplied by the manufacturer for that purpose. The average of 10 readings on the test anvil should be obtained. Specimens obtained for laboratory tests must be representative of the rock to be studied. The test surface of all specimens, either in the laboratory or in the field, must be smooth and flat over the area covered by the plunger. This 
area, and the rock material beneath to a depth of $6 \mathrm{~cm}$, should be free from cracks or any localized discontinuity of the rock mass.

At least 20 individual impact tests should be conducted on any rock sample. Test locations should be separated by at least the diameter of the plunger. Any test that causes cracking or any other visible failure will cause that test and the specimen to be rejected. The mechanism of operation is simply a spring-driven plunger impacting against the rock surface. The rebound distance of the plunger is recorded as the test result and it is read directly from a unitless numerical scale reading 0 to 80 . Calibration curves have been obtained experimentally relating the logarithm of the Schmidt hammer rebound number to the uniaxial compressive strength of rocks.

Creep is the time dependent strain or deformation under sustained axial stress. Time-dependent rock deformation data were obtained using the triaxial creep test. This test is similar to a standard triaxial compression test in that a jacketed sample is loaded while under a confining pressure. The difference is that the system is set to maintain a constant axial load rather than a constant strain rate. The engineering stress will be constant while the true stress will decrease somewhat during the test as the cross-sectional area increases. Strain is then measured through time for the test. Results are usually presented as strain/elapsed time plots or stress-strain plots. Standard test requirements for specimens are that they shall be right circular cylinders with a length to diameter ratio of 2.0 to 2.5 and a diameter of not less than $48 \mathrm{~mm}$.

Three phases of creep are generally recognized in rocks: transient creep, secondary creep, and tertiary creep (Martin et al. 1995, pp. 4-5). Transient creep is characterized by strain that decelerates rapidly as the test progresses and may account for the observed strain at low stresses. Secondary (steady-state) creep may be observed at high stresses where strain is proportional to time. If secondary creep is allowed to continue, the strain eventually increases and failure occurs. Several mechanisms for creep have been put forward: the growth of microfractures or cracks (Martin et al. 1995, pp. 5-7), pore collapse, intracrystalline gliding, micropore crushing, and grain rotation and sliding (Senseny and Parrish 1981, pp. 14-18).

The most important role of laboratory testing for repository characterization is to provide input for the development of material models that will be used in long-term computer simulations for both design and performance assessment. In addition, laboratory test results provide the opportunity for limited validation of the constitutive equations. The large variance of samples from the same locality, the relatively long time constants, and the difficulty of performing laboratory tests on jointed rock at a large enough scale to simulate an equivalent continuum, complicate the problem of rock characterization.

\section{IDENTIFICATION OF RELEVANT DATA}

\subsection{DATA TRACKING NUMBERS REVIEWED}

A systematic review of the contents of the TDMS was conducted to identify all DTNs that might contain data relevant to the properties of rock tensile strength, Schmidt hammer rebound hardness, and rock triaxial creep based on laboratory testing of intact rock properties. DTNs linked to the following TDMS parameters were reviewed for relevant data: 
- Tensile strength

- Schmidt rebound hardness

- Intact rock tensile strength

- Rock triaxial creep.

The Technical Data Parameter Dictionary element of the TDMS provides definitions for the above parameters. The search identified 91 unique DTNs in TDMS as containing potentially relevant data related to one or more of the above parameters. Each DTN was reviewed to determine if the DTN contained data relevant to the intact rock properties considered by this report. The DTNs reviewed and the resulting dispositions are listed in Table 1. The qualification status, disposition, and verification represent the status at the beginning of the review process (August 2002) and may not represent the current status.

\subsection{DATA TRACKING NUMBERS IDENTIFIED AS RELEVANT}

Table 1 identifies 16 DTNs in TDMS as containing relevant data for the parameters discussed in this report. At the start of the review, two were qualified and verified, thirteen were qualified but not verified, and one was unqualified. Of the thirteen DTNs that were qualified but not verified, all were subsequently verified as qualified in accordance with AP-3.15Q (Table 2). The DTN that was unqualified and a related report that contains relevant data that was never submitted to TDMS, are identified in Table 3. The report was identified through the review of a DTN (SNL02040687004.001) that is related to the report but did not contain relevant data itself. These two unqualified datasets contain tensile strength and rock triaxial creep data, respectively, and were considered for qualification in accordance with AP-SIII.2Q.

All relevant data for tensile strength, Schmidt hammer rebound hardness, and rock triaxial creep results were compiled from the 15 sources that were determined to be qualified by this report (Table 4, Sections 4 to 6). New DTNs were generated for the consolidated dataset of each property. The consolidated datasets include information on the results of testing and supporting information on the sample location, sample size, lithostratigraphic interval, test environmental conditions, and references to associated reports and records. In addition to the source DTNs, lithostratigraphic assignments were made using the contacts identified in DTN: MO0004QGFMPICK.000. The lithostratigraphic system used in this report follows that in DTNs MO0004QGFMPICK.000 and GS931208314211.049. Some lithostratigraphic zones for the Tiva Canyon tuff were taken from DTNs GS931008314211.039, GS931008314211.045, and GS931008314211.038. Units of measurement were converted to a common system so that comparisons and summarization of test results could be conducted. Table I-1 in Attachment I shows the lithostratigraphic system used in this report. The source DTNs also contain data for other properties that are not the focus of this report and those data were not carried forward.

\section{DATA SUMMARY}

This section summarizes the tensile strength, Schmidt hammer rebound hardness, and rock triaxial creep data by lithostratigraphic unit. The data are reviewed to evaluate trends and distributions, and to identify anomalies that require explanation. The discussion concentrates on those units for which a sufficient number of tests were run to allow this type of review. 


\subsection{TENSILE STRENGTH}

A summary of qualified Brazil tensile strength data by lithostratigraphic unit is shown in Table 5 and DTN: MO0306DQRIRPTS.002. Descriptive statistics including mean, median, standard deviation, and minimum and maximum values are shown in Table 5, along with data status, number of tests conducted, formation, and lithostratigraphic units. These data do not include data from DTN: MO0301SETSTTST.000.

The following is a brief discussion of the qualified Brazil tensile strength data summarized in Table 5. Table 5 shows that from the top toward the middle of the Tiva Canyon tuff there is a trend of increasing tensile strength, and decreasing tensile strength from the middle toward the base of the unit:

- The crystal-rich nonlithophysal zone (Tpcrn) has low tensile strength (mean of $7.75 \mathrm{MPa})$.

- The crystal-poor upper lithophysal zone (Tpcpul) has slightly higher strength (mean of $10.07 \mathrm{MPa})$.

- The highest tensile strength (mean of $15.50 \mathrm{MPa}$ ) is measured in the crystal-poor middle nonlithophysal zone (Tpcpmn).

- The crystal-poor lower nonlithophysal zone (Tpcplnh and Tpcplnc) and lower crystalpoor vitric zones (Tpcpv2) have lower tensile strength values (means of 8.96, 11.29, and 3.60 MPa respectively).

- The tensile strength values for the entire Tiva Canyon tuff ranged from a minimum of $0.50 \mathrm{MPa}$ to a maximum of $18.90 \mathrm{MPa}$.

Tensile strength measurement results for the units below the Tiva Canyon tuff (Tpc) and above the Topopah Spring tuff (Tpt) are presented in Table 5. These units consist of a series of bedded air-fall tuffs and two thin ash-flow (ignimbrite) units, the Yucca Mountain tuff (Tpy) and the Pah Canyon tuff (Tpp), each of these units exhibits very low tensile strength, generally less than $1 \mathrm{MPa}$ :

- Tensile strength for the Tpy unit is 3.0 MPa based on one test.

- Mean tensile strength for bedded air-fall tuff (Tpbt2 \& Tpbt3) is 0.20 to $0.30 \mathrm{MPa}$.

- Tensile strength for the Pah Canyon tuff (Tpp) has a mean of 0.19 MPa.

- The low tensile strength can be attributed to the high porosity (generally 30 to 50 percent) and variable lithology of these units.

The Topopah Spring tuff is zoned in a manner similar to the Tiva Canyon tuff. The tensile strength properties of these zones are also similar to those found in the Tiva Canyon tuff: 
- The upper two zones with test results, the crystal-rich nonlithophysal zone (Tptrn) and the crystal-rich lithophysal zone (Tptrl), have relatively low tensile strength values (means of 5.49 and $4.81 \mathrm{MPa}$ respectively).

- Tensile strength results increase slightly in the crystal-poor upper lithophysal zone (Tptpul) with a mean of $5.57 \mathrm{MPa}$.

- The highest tensile strengths are measured in the crystal-poor middle nonlithophysal zone (Tptpmn) and the crystal-poor lower lithophysal zone (Tptpll) with mean values of 10.88 and $8.33 \mathrm{MPa}$, respectively.

- Lower tensile strength values are observed near the base of the unit in the crystal-poor lower nonlithophysal zone (Tptpln) (mean of 7.92 MPa).

- Even lower tensile strength values are observed in the uppermost vitric subzone (Tptpv3) (mean of 3.97 MPa).

The Brazil tensile strength tests shown in Table 5 were conducted in accordance with ASTM D 3967-86 and Mellor and Hawkes (1971), and were performed by the United States Bureau of Reclamation, New England Research, Inc. (NER), and Sandia National Laboratories. All the tests were conducted under ambient temperature and pressure conditions. Most samples were saturated prior to testing, but some samples (e.g., air-fall tuff) that might disintegrate when saturated were tested under room-dry (as-received) conditions.

Additional tensile strength data from DTN MO0301SETSTTST.000 could not be qualified by this report. This source contains data obtained by both direct and indirect methods of measuring tensile strength. These data were collected as part of a preliminary study to compare the two techniques for determining the tensile strength of nonlithophysal, welded tuff of the Topopah Spring Member. The results of that testing are summarized in Table 6. Twenty-two tensile strength tests for the Topopah Spring tuff middle nonlithophysal zone (Tptpmn) were obtained from both direct and indirect tensile strength testing procedures. Samples for the direct-pull tension tests were taken from drill cores from the USW GU-3 drill hole and from a large block from an outcrop on the southwest flank of Busted Butte. Samples for the Brazil tests were taken from drill cores from the same large block from an outcrop on the southwest flank of Busted Butte. Samples for both tests were deformed in tension under dry, room temperature, constant displacement rate $\left(10^{-5} \mathrm{~mm} \mathrm{~s}^{-1}\right)$ conditions. Samples for the direct-pull tension tests were tested following the procedure discussed in Section 1.4.

Tensile strengths determined from direct-pull tests ranged from 1.94 to $11.53 \mathrm{MPa}$, with a mean of 6.07 MPa and standard deviation of 3.09 MPa. Tensile strengths determined from Brazil tests ranged from 16.01 to $26.26 \mathrm{MPa}$, with a mean of $21.69 \mathrm{MPa}$ and standard deviation of 3.39 $\mathrm{MPa}$. The resulting tensile strengths calculated from the Brazil tests are a factor of two higher than those measured on the same type of tuff by borehole Brazil tests in Table 5. There is also a substantial difference between the direct-pull tests and the Brazil tests from the same location.

One explanation as to why the results in Table 6 indicate higher tensile strength from the Brazil tests, could be a relationship between porosity and tensile strength. The Brazil tensile strength 
test data in Table 5 have porosity values included for the Brazil test specimens. A comparison of the porosity and the Brazil tensile strength test data indicates a strong correlation with lower porosities producing higher strengths. The samples used in the testing for Table 6 did not have porosity measurements. However, other porosity measurements on cores from the same block (e.g., DTN SNL02040687004.001) indicate that porosities in the Busted Butte block may be relatively low when compared to the porosities for the samples in Table 5. Another factor may be that the samples for the Tptpmn zone in Table 5 were saturated prior to testing while the samples in Table 6 were tested in a dry state. Saturation may have the same effect of reducing tensile strength as it does with compressive strength testing. Although the differences in test environment are a complicating factor, the unqualified results indicate that the test results given on Table 5 may not capture the full range of variation in tensile strength for the zones tested.

The difference between the results from the direct-pull testing and the Brazil tests are discussed by Teufel and McNamee (1991, Section 3). They indicate that the Brazil test produces failure in a biaxial stress field rather than the uniaxial stress field of the direct-pull tests. For this reason, the Brazil test generally shows a higher tensile strength than direct-pull tests. An additional related factor may be the presence of lithophysae and pumice clasts within the specimens tested. In the direct-pull test, failure may be initiated at such weak points resulting in a lower tensile strength than would be found in a specimen without such features. In the Brazil test, the compressive load is applied along the length of the specimen column, the break occurs on a predetermined plane that may not be the weakest surface, and internal weak points may be less of a factor in the result. Users of the Brazil test results in Table 5 should consider how the results may be related to the nature of the test in interpreting the values.

The variability in the tensile strength test results for each of the lithostratigraphic units included in this report is not the result of accuracy limitations in the testing equipment or procedures, but reflects the variation in characteristics of the tuff samples. These ash-flow and bedded-tuff units are heterogeneous by nature. Undetected features that could affect sample behavior include lithophysae, pumice clasts, lithic fragments, minor fractures (mineralized or open), and alteration zones. Lithophysae are characteristic of some cooling zones in the ash flows and consist of hollow, bubble-like structures composed of concentric shells of finely crystalline minerals within the rock matrix. These voids formed from air or gas trapped in the flow during deposition or exsolved from the rock during cooling. As the test results discussed above indicate, users of the data in Table 5 should consider the number of tests and spatial distribution of the sampling locations in determining how representative the results are for defining the variation that may be encountered in the repository block.

\subsection{SCHMIDT HAMMER REBOUND HARDNESS}

The summary of Schmidt hammer rebound hardness data is shown in Table 7 by lithostratigraphic unit. Each value in Table 7 represents the average of multiple impact tests conducted on each rock sample. The values shown are the "Schmidt Value" from DTN: MO0306DQRIRPSH.001 (mean of all tests with the most extreme value deleted). The DTN also gives a "Mean Value" which is the mean of all tests with no values deleted. All the tests were performed in accordance with the procedure described in Section 1.4, the suggested method for determination of the Schmidt rebound hardness by the International Society of Rock Mechanics. The Schmidt hammer rebound hardness tests were conducted in the field by the same laboratory 
under the same conditions using the same equipment and procedure. All of the field results in DTN: MO0306DQRIRPSH.001 have been compiled from sources that were verified as qualified in accordance with AP-3.15Q, Managing Technical Product Inputs.

The mean values for Schmidt hammer rebound hardness are fairly uniform throughout much of the Tiva Canyon tuff. The mean and median values for the underlying Pah Canyon tuff (Tpp) and bedded tuffs (Tpbt2) were significantly lower than the Tiva Canyon tuff. The measured values range from 16.10 to 19.50 from only one value for each unit. The low hardness values can be attributed to the high porosity (generally 30 to 50 percent) of these units.

Schmidt hammer rebound hardness values similar to the Tiva Canyon tuff were measured in the Topopah Spring tuff. Except for the vitric zones, the mean values generally range from about 42 to almost 50. The measured values ranged from a minimum value of 11.70 to a maximum value of 58.95. Because the lithostratigraphic units have basically the same chemical composition, the wide overall range in values for all the tests of the Tptpul, Tptpmn, and Tptpll can be attributed to variation in the degree of crystallization, fracturing (mineralized or open), porosity, and lithophysal development.

\subsection{ROCK TRIAXIAL CREEP}

The summary of rock triaxial creep data is shown in Tables 8 and 9. Qualified results are presented for seven creep experiments performed on welded specimens of the Tptpmn unit recovered from borehole USW NRG-7/7A. The measurements were performed at nominal differential stresses of 40,70,100, and $130 \mathrm{MPa}$. The confining pressure and temperature for each of the experiments was $10 \mathrm{MPa}$ and $225^{\circ} \mathrm{C}$, respectively. All of the specimens were tested drained, in room-dry conditions. No attempt was made to maintain the pretest concentration of water in the specimen. Water was expelled from the specimen during initial heating and the water concentration presumably remained constant or close to zero for the remainder of the test. This condition is similar to that expected in the near-field rock in repository emplacement drifts. The duration of the experiments ranged from 2.6 million seconds to 5.9 million seconds.

Martin et al. (1997, Section 2) documents the methods that were used in testing. The methods were adopted as ASTM D 4406-93, Standard Test Method for Creep of Cylindrical Rock Core Specimens in Triaxial Compression. The report included the source of samples, including project name and location (by drill hole), and the depth of sample from the collar of the hole. The lithologic description of the rock and the load direction with respect to lithology were given. The moisture condition of the sample before testing was reported as room dry. The testing was performed on seven samples from drill hole NRG-7/7A from various depths, but seismic velocity data was obtained from only six samples. Test specimens were right circular cylinders within the tolerances specified by Preparing Cylindrical Samples, Including Inspection of Dimensional and Shape Tolerances (TP-51 1990). The specimens had a length of $101.6 \mathrm{~mm}$ and a diameter of $50.8 \mathrm{~mm}$. The compression wave velocity, orthogonal polarized shear wave velocity, and radial wave velocities were measured for each of the six sample locations.

The compression and shear wave velocity measurements were performed to test specimen anisotropy by comparing the compression and shear wave velocities measured both parallel and normal to the core axis. The axial strain values and the compressive stress in the test specimen 
can be calculated from the compressive load on the specimen and the initial cross-sectional area of samples. The stress level at which the test was performed is shown in Table 8.

Tabulations of strain and time data for the creep tests are shown in Table 9. The time duration of tests varied between 29.5 days and 68.3 days. All of the tests displayed the same general pattern. Most strain was observed to occur immediately upon loading of the sample as indicated by the strain value at 1,000 seconds on Table 9. After initial loading, no time-dependent strain is observed at a stress difference of $40 \mathrm{MPa}$. At stress differences of 70, 100, and $130 \mathrm{MPa}$, the rate of strain at constant stress generally increases with increasing stress. However, there is scatter in the results and the test with a stress difference of around $130 \mathrm{MPa}$ and the longest duration showed no appreciable strain accumulation during the time interval between 1,000 and $5.9 \times 10^{6}$ seconds. All of the tests showed transient creep with the strain rate continually decreasing through time (Martin et al. 1997, p. 34). The following paragraphs provide a short discussion of each of the seven individual tests summarized from Martin et al. (1997, Section 3).

Specimens NRG-7-776.6, 807.6, and 858.4 (all Tptpmn) were tested simultaneously at differential axial stresses of 70,40, and $100 \mathrm{MPa}$, respectively; there was no visible evidence of damage to the specimens. All three experiments were terminated simultaneously at 3,700,000 seconds:

- Specimen NRG-7-807.6, with a differential stress of $40 \mathrm{MPa}$, developed a strain of 1.08 millistrain during loading. No additional significant strain accumulation was detected after 1,000 seconds (accumulated strain between 1,000 and 3.7 x $10^{6}$ was 0.08 millistrain). An O-ring on the loading piston failed at nearly 1,500,000 seconds into the test causing the strain to drop to near zero. On reloading, the specimen exhibited nearly the same strain as prior to the O-ring failure.

- Specimen NRG-7-776.6 was tested at a differential axial stress of $70 \mathrm{MPa}$. Initial loading produced a strain of 2.34 millistrain. The specimen continued to shorten throughout the test (accumulated strain between 1,000 and $3.7 \times 10^{6}$ seconds was 0.18 millistrain). The strain rate continually decreased with time. At approximately $3,700,000$ seconds the test was terminated due to a jacket failure.

- Specimen NRG-7-858.4 was tested at a differential axial stress of $100 \mathrm{MPa}$. Initial loading produced an axial strain of 2.69 millistrain. Strain accumulation continued throughout the experiment test (accumulated strain between 1,000 and 3.7 x $10^{6}$ seconds was 0.19 millistrain). The rate of strain accumulation was not constant. The strain rate was greatest in the first 1,000 seconds. Subsequently, the strain accumulation decreased to a low rate.

The test on specimen NRG-7-808.3 (Tptpmn) was conducted in a four-post frame at a nominal differential stress of $130 \mathrm{MPa}$. The experiment was terminated prior to failure after 5,900,000 seconds. The strain change with time is extremely small after initial loading (accumulated strain between 1,000 and $5.9 \times 10^{6}$ seconds is 0.04 millistrain). 
Another suite of experiments was conducted on three specimens from the Tptpln zone (NRG-71264.5, NRG-7-1281.4, and NRG-7-1400.5) at differential axial stresses of 98, 131, and 132 MPa (Martin et al. 1997, Section 3):

- Specimen NRG-7-1264.5 shows a significant transient strain upon initial loading. The inelastic strain change was greatest in the first several thousand seconds. After the specimen was subjected to stress for approximately 1,000 seconds, the strain rate decreased markedly. At approximately 2,570,000 seconds the jacket on the specimen failed and the experiment was terminated. An examination of specimen NRG-7-1264.5 showed no apparent damage to the specimen.

- Specimens NRG-7-1281.4 and NRG-7-1400.5 were tested at a nominal stress difference of $130 \mathrm{MPa}$. The behavior of both samples was very similar. Both showed significant transient strain at times less than one thousand seconds. The strain rate was not constant. Strain accumulated throughout the experiment, but the rate decreased with time. Specimen NRG-7-1400.5 showed no external indication of damage. A post-test examination of specimen NRG-7-1281.4 shows spalling and cracking around a vapor-phase altered zone. This suggested to Martin et al. (1997, p. 34) that microcracking was occurring during testing.

Prior to the constant rate creep tests discussed above, a group of other creep tests was conducted by the YMP. These tests are discussed in Senseny and Parrish (1981), Martin et al. (1991), and Martin et al. (1995). All of these tests are unqualified. The creep results from these tests are presented graphically rather than numerically and, therefore, the data were not submitted to TDMS. However, the sonic velocity results from these tests were submitted to TDMS and are identified in DTN SNL02040687004.001. Because this DTN identifies no creep data, it is not considered further in this report. The creep results in Martin et al. (1995) were evaluated for qualification to determine if they supported the findings from the qualified tests. The earlier data in Senseny and Parrish (1981) are described below but were not evaluated for qualification because a different stratigraphic unit was tested. The earlier data in Martin et al. (1991) are also described below, but were not evaluated for qualification because only one sample was tested and the sample was subjected to multiple testing cycles.

Senseny and Parrish (1981, Section 2) tested four specimens from the Bullfrog Member of the Crater Flat tuff taken from the UE-25 A\#1 borehole. These welded tuff samples were tested at $100^{\circ} \mathrm{C}$ and at axial stresses near the unconfined compressive strength. Three tests were conducted on oven-dried samples at confining pressures of 0.7 to $3.5 \mathrm{MPa}$. One test was conducted on a saturated specimen at a confining pressure of $1.4 \mathrm{MPa}$, a pore pressure of 0.7 $\mathrm{MPa}$, and an axial stress difference of 60 percent of dry unconfined compressive strength. The duration of the tests ranged from 21 to 34 days. Results were similar to that observed in the qualified tests. Only transient creep was observed with the strain rate decreasing through time. Total axial creep strains at the end of tests were variable between the samples tested, but were all low (about 0.5 millistrain). Creep rates in the saturated specimen were substantially higher than those in the oven-dried specimens. While Martin et al. (1997, pp. 34-42) favored microfracturing and cracking as the creep mechanism for their samples, Senseny and Parrish (1981, p. 17) suggested that micropore crushing may have been the creep mechanism based on microscopic examination. 
Martin et al. (1991, Section 5.3) performed creep testing on one sample from a surface outcrop at Busted Butte (Tptpmn zone). Several creep tests were performed on the same specimen. The specimen was saturated and tested at a confining pressure of $5 \mathrm{MPa}$ and a pore pressure of 4.5 $\mathrm{MPa}$. The sample was first tested at room temperature and a differential stress of $49 \mathrm{MPa}$. No change in axial strain was observed after initial loading during the 181-hour test. The differential stress was removed and the sample was again tested at a temperature of $250^{\circ} \mathrm{C}$ and a differential stress of $50 \mathrm{MPa}$. Two initial tests at this temperature encountered mechanical problems and were terminated. The third test ran for 168 hours and recorded no axial strain after initial loading. A final test was run at $250^{\circ} \mathrm{C}$ and differential stress of $70 \mathrm{MPa}$. After initial loading, the specimen showed no or very little (less than 0.1 millistrain) axial strain until the sample failed at about 62 hours due to jacket failure. These tests again tend to corroborate the qualified tests in that very low creep strains were recorded.

Martin et al. (1995, Section 3.0) conducted tests to determine the effects of elevated temperature and stress on the creep deformation of welded tuffs recovered from Busted Butte in the vicinity of Yucca Mountain, Nevada. Water saturated specimens of tuff were tested in creep at a confining pressure of 5.0 MPa, a pore pressure of $4.5 \mathrm{MPa}$, and temperatures of 25 and $250{ }^{\circ} \mathrm{C}$. These tests were primarily scoping in nature and the method used to evaluate the creep response of the tuff was conducted in a reconnaissance mode. The tests did not adhere to conventional American Society for Testing and Materials standards, and insufficient data were collected to determine the relationship between temperature, stress creep deformation to failure, and total failure time at a fixed creep stress. However, a variation of constant strain rates during conventional triaxial creep has been used as a method to describe time-dependent deformation.

Specimen BB-10AE-36Z-SNL (Martin et al. 1995, Section 3.1) was tested at ambient and $250^{\circ} \mathrm{C}$ temperature. In the ambient temperature test, Specimen BB-10AE-36Z-SNL was subjected to increasing differential stresses of $50,60,70$, and finally $80 \mathrm{MPa}$. The load was removed after $1.45 \times 10^{6}$ seconds. About 0.1 millistrain of permanent strain was noted after this loading cycle. The elevated temperature test had an initial differential axial stress of $58 \mathrm{MPa}$ applied to the specimen. At periodic intervals the stress was increased to 69 and finally $79 \mathrm{MPa}$. After a cumulative duration of 3.2 million seconds, the specimen was unloaded because of furnace failure. The large majority of the deformation occurred during the loading of the specimen. Small amounts of time-dependent axial strain were noted during the constant stress segments of the time history (strain rate of approximately $10^{-10} \mathrm{~s}^{-1}$ ). The time-dependent deformation occurred almost exclusively as transient creep.

Specimen BB-9394-SNL-A (Martin et al. 1995, Section 3.1) was tested at ambient temperature. Specimen BB-9394-SNL-A had an initial $50 \mathrm{MPa}$ differential axial stress applied to the specimen. The load on the specimen was incremented by $10 \mathrm{MPa}$ at intervals until the rock failed at a differential axial stress of $130 \mathrm{MPa}$. The total duration of the test was almost 79 days. At stresses below $100 \mathrm{MPa}$, almost all of the strain accumulation occurs during the incremental loading. After the stress was increased to $110 \mathrm{MPa}$, a small axial strain rate was detected. Subsequent stress increases were made to $120 \mathrm{MPa}$ and finally $130 \mathrm{MPa}$. The strain rate during the constant stress portion of the curve increased further. As with specimen BB-10AE-36ZSNL-A, this data can be plotted as conventional stress-strain curves where the curve is similar to those in a constant rate experiment. 
Specimen BB-10AE-22Y-SNL (Martin et al. 1995, Section 3.2) was initially tested in creep at room temperature and a differential axial stress of $80 \mathrm{MPa}$. After the specimen was unloaded, the temperature was increased and the specimen was tested once again at a temperature of $250^{\circ} \mathrm{C}$. The confining and pore pressures were the same as for the room temperature conditions. The differential axial stress on the sample was $79 \mathrm{MPa}$. The experiment was terminated after approximately 17 hours when the specimen failed. Most axial and radial strain occurred during loading and at failure of the specimen. Axial strains during the constant stress segment of the test were less than 0.1 millistrain.

The general results from the previous unqualified tests tend to corroborate the results of the qualified tests that creep rates are very low in welded tuffs.

\section{DATA QUALIFICATION METHODS}

The basic review of data in this report identified both qualified and unqualified sources. In accordance with AP-SIII.2Q, the following sections document the data qualification task that evaluated some of the unqualified sources. The qualification method of corroboration will be used to assess whether the unqualified tensile strength and triaxial creep data should be included in DTNs MO0306DQRIRPTS.002 and MO0306DQRIRPTC.001. All data in DTN: MO0306DQRIRPSH.001 for Schmidt hammer rebound hardness tests were verified as qualified based on AP-3.15Q.

The corroborating data method involves comparing different datasets to evaluate the consistency between sets of independently acquired data. As stated in AP-SIII.2Q, the corroborating data approach may include comparisons between qualified and unqualified data. A requirement for using the corroboration method is that a sufficient quantity of corroborating data is available for comparison with the unqualified dataset(s).

\subsection{EVALUATION CRITERIA}

The unqualified data will be evaluated for qualification based on consideration of the following criteria. This criteria was selected to incorporate the considerations in AP-SIII.2Q, Attachment 2; the applicable qualification process attributes listed in AP-SIII.2Q, Attachment 3; and the data-specific considerations identified in Sections 3 and 5 of this report. The selected criteria have been modified from those stated in the Technical Work Plan to accommodate changes in procedures and response to $\mathrm{BSC}(\mathrm{O})-03-\mathrm{D}-129$. The following are the criteria used for consideration of unqualified data for inclusion in DTNs MO306DQRIRPTS.002 and MO0306DQRIRPTC.001. The first four criteria relate to the initial evaluation of the data quality and correctness that is required by AP-SIII.2Q. The last criterion relates to the application of the corroborating data method.

- Are the data collection methods reasonable in view of standard measurement and instrumentation practice at the time the data were collected?

- Are the qualifications of the personnel or organizations generating the data comparable to qualification requirements of personnel generating similar data under the approved 10 CFR 60, Subpart G, QA program? 
- Are these data, or similarly collected data, generally accepted by the technical community for use in non-YMP applications?

- Is the documentation associated with the data sufficient to allow an assessment of the methods used and the results obtained?

- Does analysis of comparable qualified and unqualified datasets indicate a reasonable level of accuracy for the testing?

\subsection{RECOMMENDATION CRITERIA}

Qualification of data is to be based on a determination by the qualification team that the data respond to the evaluation criteria in a substantially positive manner, and are found by the team to be adequate for generalized use by the YMP. The inherent variability in earth science data means that a qualification review cannot assess the accuracy or precision of individual data points with certainty. A generalized use of data is, therefore, a use wherein conclusions are not based on the precise value of a single data point, but are based on the cumulative evidence of many corroborating data points. This report attempts to summarize the available data for such a generalized use by focusing on general trends or ranges of values rather than on individual points. A generalized use of data is, therefore, most appropriate for data points with mixed origin and pedigree.

\section{DATA QUALIFICATION RESULTS}

The Sandia National Laboratories, U.S. Geological Survey, and a group of commercial laboratories were contracted to collect the data on tensile strength and rock creep. An initial evaluation of the quality and correctness of the unqualified data will first be made through a review of the documentation and methods used. This will be followed by a comparison of the unqualified datasets to the qualified data.

\subsection{TENSILE STRENGTH DATA}

A summary of qualified data for tensile strength by lithostratigraphic unit is shown in Table 5 . Descriptive statistics including mean, median, standard deviation and minimum and maximum values are shown, along with the number of tests conducted, the formation, and lithostratigraphic units. This dataset will be used to compare with the unqualified tensile strength dataset in Table 6. All of the tensile strength data in Table 5 have been classified as verified and qualified in accordance with AP-3.15Q. The collection of the data in Table 5 was conducted in accordance with the applicable portions of ASTM D-3967-86 and ASTM D-3967-92. Table 5 contains data from 14 Brazil tensile strength tests in the Tptpmn lithostratigraphic unit. The descriptive statistics shown in Table 5 for tensile strength tests ranged from 4.30 to $16.80 \mathrm{MPa}$ with a mean of $10.88 \mathrm{MPa}$ and standard deviation of $4.02 \mathrm{MPa}$.

Table 6 contains data from 22 tensile strength tests obtained from both direct and indirect tensile strength testing methods. These tests were conducted by Sandia National Laboratories (SNL) and are reported in DTN: MO0301SETSTTST.000. The tests were conducted to compare the two techniques for determining the tensile strength for the Tptpmn lithostratigraphic unit. 
Samples for the 11 direct-pull tension tests were taken from drill holes in the Tptpmn unit from the USW GU-3 borehole and from a large outcrop block on the southwest flank of Busted Butte. Samples for the 11 Brazil tests were also taken from the same outcrop block on the southwest flank of Busted Butte. Samples for both tests were deformed in tension under dry, room temperature constant displacement rate $\left(10^{-5} \mathrm{~mm} \mathrm{~s}^{-1}\right)$ conditions. The data in Table 6 were collected in accordance with the applicable portions of ASTM D-3967-86 and ASTM D-396792. These supporting records for the procedures and testing process are documented in the records shown in Table 10. This documentation indicates that the data were collected under standard procedures and can be considered technically correct.

The results shown in Table 6 for tensile strength determined from direct-pull tests ranged from 1.94 to $11.53 \mathrm{MPa}$ with a mean of $6.07 \mathrm{MPa}$ and standard deviation of $3.09 \mathrm{MPa}$. Tensile strengths determined from Brazil tests ranged from 16.01 to $26.26 \mathrm{MPa}$ with a mean of 21.69 $\mathrm{MPa}$ and a standard deviation of $3.39 \mathrm{MPa}$. The combined mean tensile strength value for 22 tensile strength tests is $13.88 \mathrm{MPa}$ with a median tensile strength value of $13.77 \mathrm{MPa}$.

Comparing the two Brazil tensile strength test datasets shows only a small number of values (three) in the 16.0 MPa range that appear in common between the two sets of tensile strength data. Table 5 data has a range of values from 4.30 to $16.80 \mathrm{MPa}$ and Table 6 data has a range of values from 16.01 to $26.26 \mathrm{MPa}$. The resulting mean tensile strength for Table 6 data calculated from the Brazil tests is a factor of two higher than those measured on the same type of tuff from borehole samples in Table 5 (21.69 Vs $10.88 \mathrm{MPa})$. There appears to be very little corroboration between Table 5 and Table 6 Brazil tensile strength data with only approximately sixteen percent of the values intersecting the range between the two datasets. There are no corroborating datasets for the direct-pull tests.

\subsection{ROCK TRIAXIAL CREEP}

A review of the rock triaxial creep data in Tables 8 and 9 shows that the testing was conducted in accordance with the applicable portions of ASTM D 4406-93, which was in the approval process at the time of testing. The data and reports document that the standard was followed. The testing for acquiring the data in Martin et al. (1995) was not fully conducted in accordance with the applicable portions of ASTM D 4406-84 (i.e., differential stress was varied through the course of the test), this is also documented in the record. The data from Tables 8 and 9 were verified in accordance with AP-3.15Q, and were included in the summary DTN: MO0306DQRIRPTC.001. The data in Martin et al. (1995) (not verified under AP-3.15Q) were collected by NER and have been included in the data to be considered for qualification in accordance with AP-SIII.2Q. NER operated as an SNL subcontractor for this work. NER is a commercial laboratory in White River Junction, Vermont, that performs laboratory rock properties measurements. Their primary business is using laboratory core measurements and modeling techniques for oil, gas, and geothermal reservoir evaluations.

Surveys of the QA program implemented by NER were conducted during the time frame that the work by Martin et al. (1995) was completed (Hawkinson 1993; Hawkinson 1994). These surveys indicate that the QA program was in compliance with the Quality Assurance Requirements and Description requirements in place at the time that work was conducted. These surveys also included a review of the qualifications of the personnel who generated the data, and 
they were judged to meet the qualification requirements for generating data under a 10 CFR 60, Subpart G, QA program. These procedures and testing processes are documented in Table 10. As discussed in Section 3.3, the unqualified and qualified data corroborate each other in a general sense, but more detailed comparisons are difficult because of the different testing methods used.

\section{DATA QUALIFICATION EVALUATION}

\subsection{TENSILE STRENGTH DATA}

The conclusions from the Data Qualification Team's review of the unqualified tensile strength data in Table 6 are presented below in terms of the five evaluation criteria presented in Section 4.1 .

A. Are the data collection methods reasonable in view of standard measurement and instrumentation practice at the time the data were collected?

The review in Section 5.1 and the records in Table 10 demonstrate that the data in Tables 5 and 6 were acquired in conformance with testing standards in place at the time the data were collected. Busted Butte and borehole samples of the Tptpmn lithostratigraphic unit were deformed in tension under dry, room temperature, constant displacement rate $\left(10^{-5} \mathrm{~mm} \mathrm{~s}^{-1}\right)$ conditions. Standard methods were used for both direct-pull-tension tests and Brazil tests of tensile strength and are documented by submitted records. Thus, the data collection methods appear reasonable in view of the standard measurement and instrumentation practice at the time the data were collected.

B. Are the qualifications of the personnel or organizations generating the data comparable to qualification requirements of personnel generating similar data under the approved 10 CFR 60, Subpart G, QA program?

The organization generating the data (SNL) is judged to meet the qualification requirements for generating data under a 10 CFR 60, Subpart G, QA program. SNL currently has acceptable QA programs in place that use basically the same staff, procedures, and equipment that were used for the qualified and unqualified testing.

C. Are these data, or similarly collected data, generally accepted by the technical community for use in non-Yucca Mountain Project applications?

Tensile strength testing in Table 6 was conducted under industry standard procedures that are used in civil, mining, and oil and gas projects. The testing procedures have a long and extensive history of development and use, and are not considered experimental or unique. The engineering and technical communities accept the products of this laboratory for similar collected data.

D. Is the documentation associated with the data sufficient to allow an assessment of the methods used and the results obtained? 
The unqualified sources have substantial documentation on the procedures used, calibration techniques used, and the data obtained. The documentation is comparable to the critical documents that would be expected for a qualified program. The documentation in Teufel and McNamee (1991) and the records listed in Table 10 are sufficient to allow assessment of the methods used and results obtained.

E. Does analysis of comparable qualified and unqualified datasets indicate a reasonable level of accuracy for the testing?

The comparisons discussed in Section 5.1 indicate that the qualified and unqualified data for the same lithostratigraphic unit, tested under similar conditions, do not yield a similar range of results. Such comparisons must be tempered with the knowledge that the laboratories were not testing the same specimens and the substantial variation within a particular lithostratigraphic unit will result in substantial scatter in every comparison. This factor means that the number of samples tested is important in evaluating these comparisons. With these restrictions in mind, the comparisons between data in Tables 5 and 6 indicate an indeterminate judgment on whether there are substantial differences between the datasets that are presented in Table 5 and Table 6.

\subsection{ROCK TRIAXIAL CREEP}

The conclusions from the Data Qualification Team's review of the rock triaxial creep data are presented below in terms of the five evaluation criteria presented in Section 4.1.

A. Are the data collection methods reasonable in view of standard measurement and instrumentation practice at the time the data were collected?

The review in Section 5.2 and the records in Table 10 demonstrate that the data collection and equipment calibration techniques for rock triaxial creep data in the unqualified dataset were not conducted in accordance with the applicable portions of ASTM D 4406-84 and D 4406-93. However, the data collection methods appear reasonable in view of the scoping nature of study.

B. Are the qualifications of the personnel or organizations generating the data comparable to qualification requirements of personnel generating similar data under the approved 10 CFR 60, Subpart G, QA program?

The organization generating the data (NER) is judged to meet the qualification requirements for generating data under a 10 CFR 60, Subpart G, QA program. QA programs were in place that use basically the same staff, procedures, and equipment that were used for the qualified and unqualified testing. A survey of NER's QA programs was conducted during the time frame that work was completed by the organization that contracted the work (SNL). Hawkinson 1993 and Hawkinson 1994 indicate that the QA program was in compliance with U.S. Department of Energy standards in place at the time work was conducted. These surveys also included a review of the qualifications of the personnel who generated the data, and they were judged to meet the qualification requirements for generating data under a 1060 , Subpart G, QA program. 
C. Are these data, or similarly collected data, generally accepted by the technical community for use in non-Yucca Mountain Project applications?

Rock triaxial creep testing is an industry standard test that is used in civil and mining projects. The testing procedures have a long and extensive history of development and use and are not considered experimental or unique. The commercial laboratory being evaluated (NER) routinely conducts this type of testing for industry clients. The engineering and technical community for other projects generally accepts the products of this laboratory for use in non-Yucca Mountain Project applications.

D. Is the documentation associated with the data sufficient to allow an assessment of the methods used and the results obtained?

The documentation associated with Martin et al. (1995) is sufficient to allow an assessment of the methods used and results obtained. The unqualified sources have substantial documentation on the procedures followed, calibration techniques used, and the data obtained. However, the documentation indicates that the data were from a scoping study on creep and that it was not the intent of the study to gather quasi-static data. There were not enough data gathered to warrant confident presentation of the rock triaxial creep parameter even though the data collected did appear to compare well with some of the qualified data.

E. Does analysis of comparable qualified and unqualified datasets indicate a reasonable level of accuracy for the testing?

The rock triaxial creep testing data contained in DTN: MO0306DQRIRPTC.001 and summarized in Tables 8 and 9 can only be compared to the results in Martin et al. (1995) in a general sense. The data show the same trend of varying strain rates during creep testing, but the differences in testing methods do not allow a more detailed comparison. The data collected in Martin et al. (1995) were collected in a reconnaissance mode. The tests did not adhere to conventional American Society for Testing and Materials standards and insufficient data were collected to determine the relationship between temperature, stress creep deformation to failure, and total failure time at a fixed creep stress.

\section{CONCLUSIONS}

The Data Qualification Team compiled the qualified tensile strength data in DTN: MO0306DQRIRPTS.002 and summarized the data by lithostratigraphic unit in Table 5. Based on the results of the evaluation in Sections 5 and 6, the unqualified data in Table 6 were found not to be corroborated by the data in Table 5. Therefore, the data in DTN: MO301SETSTTST.000 was not determined to be qualified and was not included in data compiled in DTN: MO0306DQRIRPTS.002. Since the data collection methods and documentation appear to be adequate for the tensile strength data in MO301SETSTTST.000, users should consider the impact of these tests when evaluating the range of variation that may be present in the Tptpmn lithostratigraphic zone. 
The qualification team compiled Schmidt rebound hardness data in DTN: MO0306DQRIRPSH.001. All relevant data were qualified and verified at the beginning of the data review. The recommended values that were developed from the compiled data in the form of descriptive statistics are shown in Table 7.

The Data Qualification Team compiled qualified rock triaxial creep data in DTN: MO0306DQRIRPTC.001 and summarized the data in Tables 8 and 9. The unqualified data in Martin et al. (1995) were found not to be corroborated by other datasets and are not included in DTN: MO0306DQRIRPTC.001. However, the unqualified data from Martin et al. (1995) and earlier studies provide increased confidence that the low creep rates documented in the limited number of qualified tests are reasonably representative of the welded tuff units.

These summaries and supporting information and discussion will be included in a RIB data item that summarizes the output from this report. Depending on their need, individual users may use individual test results from the summary DTNs or the summarized data in the RIB data item. In either case, users must consider the impact of stratigraphic and lithologic variability, the variability in environmental testing conditions, and the various methods used in collecting the intact rock property data when applying these results to specific problems.

\section{REFERENCES}

\subsection{DOCUMENTS CITED}

Cikanek, E.M.; Blakely, R.J.; Grant, T.A.; and Safley, L.E. 2003. Technical Work Plan for: Data Qualification and Summary Report of Intact Rock Properties Data on Tensile Strength, Schmidt Hammer Rebound Hardness, and Rock Triaxial Creep. TWP-MGR-GE-000003 REV 01. Las Vegas, Nevada: Bechtel SAIC Company. ACC: DOC.20030616.0001

DOE (U.S. Department of Energy) 2003. Quality Assurance Requirements and Description. DOE/RW-0333P, Rev. 13. Washington, D.C.: U.S. Department of Energy, Office of Civilian Radioactive Waste Management. ACC: DOC.20030422.0003.

Hawkinson, D.R. 1993. Quality Assurance Annual Evaluation. QA Evaluation No. NER-E93-1. [White River Junction, Vermont]: New England Research. ACC: NNA.19931215.0074.

Hawkinson, D.R. 1994. Quality Assurance Annual Evaluation. QA Evaluation No. NER-E94-1. White River Junction, Vermont: New England Research. ACC: MOL.19950208.0064.

Martin, R.J., III.; Boyd, P.J.; Noel, J.S.; and Price, R.H. 1991. Procedure Development Study: Low Strain Rate and Creep Experiments. SAND91-0527. Albuquerque, New Mexico: Sandia National Laboratories. ACC: NNA.19911010.0047.

Martin, R.J.; Price, R.H.; Boyd, P.J.; and Noel, J.S. 1994. Bulk and Mechanical Properties of the Paintbrush Tuff Recovered from Borehole USW NRG-6: Data Report. SAND93-4020. Albuquerque, New Mexico: Sandia National Laboratories. ACC: MOL.19940811.0001. 
Martin, R.J., III; Price, R.H.; Boyd, P.J.; and Noel, J.S. 1995. Creep in Topopah Spring Member Welded Tuff. SAND94-2585. Albuquerque, New Mexico: Sandia National Laboratories. ACC: MOL.19950502.0006.

Martin, R.J.; Noel, J.S.; Boyd, P.J.; and Price, R.H. 1997. Creep Properties of the Paintbrush Tuff Recovered from Borehole USW NRG-7/7A: Data Report. SAND95-1759. Albuquerque, New Mexico: Sandia National Laboratories. ACC: MOL.19971017.0661.

Mellor, M. and Hawkes, I. 1971. "Measurement of Tensile Strength by Diametral Compression of Discs and Annuli." Engineering Geology, 5, 173-225. Amsterdam, The Netherlands:

Elsevier. TIC: 253847.

Senseny, P. E. and Parrish, D. K. 1981. Creep Experiments on Welded Tuff from the Bullfrog Member of the Crater Flat Tuff, Nevada Test Site. RSI-0136. Rapid City, South Dakota:

RE/SPEC Inc.. ACC: NNA.19940608.0307.

Teufel L.W. and McNamee M.J. 1991. Tensile Strength Testing of Topopah Spring Tuff. SAND91-0044. Albuquerque, New Mexico: Sandia National Laboratories.

ACC: NNA.19910322.0056.

TP-51, Rev. A. 1990. Preparing Cylindrical Samples, Including Inspection of Dimensional and Shape Tolerences. [Albuquerque, New Mexico]: Sandia National Laboratories. ACC: NNA.19900628.0101.

\subsection{CODES, STANDARDS, REGULATIONS:}

10 CFR 60. Energy: Disposal of High-Level Radioactive Wastes in Geologic Repositories. Readily available.

ASTM D 3967-86. 1986. Standard Test Method for Splitting Tensile Strength of Intact Rock Core Specimens. Philadelphia, Pennsylvania: American Society for Testing and Materials. TIC: 231530.

ASTM D 3967-92 (Reapproved 1992). Standard Test Method for Splitting Tensile Strength of Intact Rock Core Specimens. Philadelphia, Pennsylvania: American Society for Testing and Materials. TIC: 104130.

ASTM D 4406-84. 1984. Standard Test Method for Creep of Cylindrical Rock Core Specimens in Triaxial Compression. Philadelphia, Pennsylvania: American Society for Testing and Materials. TIC: 231530.

ASTM D 4406-93 (Reapproved 1998). 1993. Standard Test Method for Creep of Cylindrical Rock Core Specimens in Triaxial Compression. West Conshohocken, Pennsylvania: American Society for Testing and Materials. TIC: 247124. 


\subsection{PROCEDURES}

AP-3.11Q Rev. 3, ICN 4. Technical Reports. Washington, D.C.: U.S. Department of Energy, Office of Civilian Radioactive Waste Management. ACC: DOC.20030331.0002.

AP-3.15Q Rev. 4, ICN 02. Managing Technical Product Inputs. Washington, D.C.: U.S. Department of Energy, Office of Civilian Radioactive Waste Management. ACC: DOC.20030627.0002.

AP-SIII.2Q, Rev. 1, ICN 1. Qualification of Unqualified Data. Washington, D.C.: U.S. Department of Energy, Office of Civilian Radioactive Waste Management. ACC: DOC.20030422.0008.

AP-SIII.4Q, Rev. 0, ICN 5. Development, Review, Online Placement, and Maintenance of Individual Reference Information Base Data Items. Washington, D.C.: U.S. Department of Energy, Office of Civilian Radioactive Waste Management. ACC: MOL.20020102.0201.

\subsection{SOURCE DATA, LISTED BY DATA TRACKING NUMBER}

GS920983114220.001. Log of Test Pit or Auger Hole, Physical Properties Summary, Gradation Test, and Summary of Physical Properties Test Results for Hole Numbers NRSF-TP-11, TP-19, TP-21, TP-25, TP-28, TP-29, and TP-30. Submittal date: 09/03/1992.

GS920983114220.002. Drill Hole UE-25 NRG-1 Rock Core Tests. Submittal date: 10/14/1992.

GS921283114220.003. Relative Density Determination, Lab Tests of Physical Properties, North Ramp. Submittal date: 12/03/1992.

GS921283114220.004. Summary Access Road Test Pit Data, Logs of Visual Observations of Site and Test Pit. Submittal date: 12/03/1992.

GS921283114220.005. Physical Properties and Dimensional Tolerance Conformance of Rock Core Test Specimens. Submittal date: 12/03/1992.

GS921283114220.006. Pulse Velocities and Ultrasonic Elastic Constants of Intact Rock Core Test Specimens. Submittal date: 12/03/1992.

GS921283114220.007. Direct Shear Test Results - Intact Rock and Sliding Friction, Borehole UE-25 NRG\#1. Submittal date: 12/03/1992.

GS921283114220.010. Splitting Tensile Strength of Intact Rock Core Specimens from UE-25 NRG\#1. Submittal date: 12/04/1992.

GS921283114220.014. Soil and Rock Geotechnical Investigations, Field and Laboratory Studies, North Ramp Surface Facility, Exploration Studies Facility, Yucca Mountain Project, Nevada. Submittal date: 12/04/1992. 
GS931008314211.038. Graphical Lithologic Log of Borehole NRG-2A (UE-25 NRG\#2A), Version 1.0. Submittal date: 10/07/1993.

GS931008314211.039. Graphical Lithologic Log of Borehole NRG-2 (UE-25 NRG\#2), Yucca Mountain, Nevada. Submittal date: 10/07/1993.

GS931008314211.045. Graphical Lithologic Log of Bore Hole USW NRG-6. Submittal date: 10/07/1993.

GS931208314211.049. Revised Stratigraphic Nomenclature and Macroscopic Identification of Lithostratigraphic Units of the Paintbrush Group Exposed at Yucca Mountain, Nevada.

Submittal date: 10/12/1993.

LL940800104244.000. Compilation of Insulating Material Properties for Use in the Large Block Test. Submittal date: 08/09/1994.

LL960905005911.010. Engineered Materials Characterization Report for the Yucca Mountain Site Characterization Project. Submittal date: 09/20/1996.

LL981112505924.050. Stress Corrosion Cracking of NI-Base and TI Alloys under Controlled Potential. Submittal date: 11/30/1998.

LL981212005924.062. Degradation Mode Survey Candidate Titanium-Base Alloys for Yucca Mountain Project Waste Package Materials. Submittal date: 12/22/1998.

LL990201804243.031. Geomechanical Analysis of the Large Block Test (MOL-236).

Submittal date: 02/08/1999.

LL990704905924.085. Cracking of Titanium Alloys Under Cathodic Applied Electrochemical Potential. Submittal date: 07/20/1999.

MO0001SEPSRMPC.000. Summary of Rock Mass Properties for Confining Stress Ranging from 0 to 42 MPA. Submittal date: $01 / 11 / 2000$.

MO0003RIB00071.000. Physical and Chemical Characteristics of Alloy 22. Submittal date: $03 / 13 / 2000$.

MO0003RIB00072.000. Physical and Chemical Characteristics of Steel, A 516. Submittal date: 03/13/2000.

MO0003RIB00073.000. Physical and Chemical Characteristics of TI Grades 7 and 16. Submittal date: $03 / 13 / 2000$.

MO0003RIB00076.000. Physical and Chemical Characteristics of Type 316N Grade. Submittal date: $03 / 14 / 2000$.

MO0003RIB00079.000. Rock Mechanical Properties. Submittal date: 03/30/2000. 
MO0004QGFMPICK.000. Lithostratigraphic Contacts from MO9811MWDGFM03.000 to be Qualified Under the Data Qualification Plan, TDP-NBS-GS-000001. Submittal date: 04/04/2000.

MO0103SEPSMRMP.000. Summary of Rock Mass Properties. Submittal date: 03/13/2001. MO0109RIB00049.001. Waste Package Material Properties: Neutron Absorbing Materials. Submittal date: 09/17/2001.

MO0204EBSPYMPG.017. Physical and Mechanical Properties of Grout. Submittal date: $04 / 23 / 2002$.

MO0204RIB00133.000. Rock Tensile Strength (Brazilian Method). Submittal date: 04/03/2002. MO0204RIB00135.000. Rock Tensile Strength (Direct Pull). Submittal date: 04/04/2002.

MO0204RIB00146.000. Schmidt Rebound Hardness. Submittal date: 04/03/2002.

MO0205UCC024KZ.019. Results of Tensile Testing of Alloy C22 Under Various Strain Rates. Submittal date: 05/29/2002.

MO0205UCC024KZ.020. Results of Tensile Test of Stainless Steel 316L Under Various Strain Rates. Submittal date: 05/29/2002.

MO0205UCC024KZ.021. Results of Tensile Testing of Titanium Alloy Grade 7 Under Various Strain Rates. Submittal date: 05/29/2002. Imaging in Process

MO0301SETSTTST.000. Tensile Strength Testing of Topopah Spring Tuff. Submittal Date: 01/09/2003.

MO9808RIB00041.000. Reference Information Base Data Item: Rock Geomechanical Properties. Submittal date: 08/05/1998.

MO9906RIB00048.000. Waste Package Material Properties: Waste Form Materials. Submittal date: 6/9/1999.

MO9906RIB00049.000. Waste Package Material Properties: Neutron Absorbing Materials. Submittal date: 06/16/1999.

MO9906RIB00050.000. Waste Package Material Properties: Ceramic Coating Materials. Submittal date: 06/16/1999.

MO9906RIB00052.000. Waste Package Material Properties: Corrosion Resistant Materials. Submittal date: 06/17/1999.

MO9906RIB00053.000. Waste Package Materials Properties: Corrosion Allowance and Basket Materials. Submittal date: 06/17/1999. 
MO9906RIB00054.000. Waste Package Material Properties: Structural Materials. Submittal date: $06 / 17 / 1999$.

MO9911SEPGRP34.000. Geotechnical Rock Properties. Submittal date: 11/10/1999.

SNF29041993002.010. Schmidt Hammer Test Data from NRG Drillholes Core. Submittal date: $12 / 17 / 1993$.

SNF29041993002.024. Schmidt Hammer Test Data from USW NRG-7/7A Drillhole. Submittal date: $04 / 18 / 1994$.

SNF29041993002.031. Rock Mass Mechanical Properties Estimates for Boreholes UE25 NRG1, NRG-2, NRG-2A, NRG-3, NRG-4, NRG-5, USW NRG-6, and NRG-7/7A (Revision 2).

Submittal date: 12/05/1994.

SNL02000000011.000. Matrix Compressive Tests of the Topopah Spring Member in USW GU 3. Submittal date: 09/23/1992.

SNL02000000012.000. Uniaxial and Triaxial Compression Test Series on Topopah Spring Tuff. Submittal date: 01/04/1985.

SNL02030180001.001. Matrix Compressive Tests to Characterize Tuffs from UE-25A\#1 and the Laser Drift in G-Tunnel. Submittal date: 08/20/1985.

SNL02030193001.002. Mechanical Properties Data for Drillhole USW NRG-6 Samples from Depth $22.2 \mathrm{ft}$. to $427.0 \mathrm{ft}$. Submittal date: 06/25/1993.

SNL02030193001.003. Mechanical Properties Data for Drillhole UE-25 NRG-2 Samples from Depth $150.5 \mathrm{ft}$. to $200.0 \mathrm{ft}$. Submittal date: 07/07/1993.

SNL02030193001.004. Mechanical Properties Data for Drillhole USW NRG-6 Samples from Depth 462.3 ft. to 1085.0 ft. Submittal date: 08/05/1993.

SNL02030193001.005. Mechanical Properties Data for Drillhole UE-25 NRG\#3 Samples from Depth $15.4 \mathrm{ft}$. to $297.1 \mathrm{ft}$. Submittal date: 09/23/1993.

SNL02030193001.006. Mechanical Properties Data for Drill Hole UE-25 NRG\#2A Samples from Depth $90.0 \mathrm{ft}$. to $254.5 \mathrm{ft}$. Submittal date: 10/13/1993.

SNL02030193001.009. Mechanical Properties Data for Drill Hole UE-25 NRG\#5 Samples from Depth 781.0 ft. to 991.9 ft. Submittal date: 11/18/1993.

SNL02030193001.013. Mechanical Properties Data for Drillhole UE25 NRG-2B Samples from Depth $2.7 \mathrm{ft}$. to $87.6 \mathrm{ft}$. Submittal date: 12/02/1993.

SNL02030193001.014. Mechanical Properties Data for Drillhole UE25 NRG-4 Samples from Depth $378.1 \mathrm{ft}$. to $695.8 \mathrm{ft}$. Submittal date: 01/31/1994. 
SNL02030193001.017. Mechanical Properties Data for Drillhole USW NRG-7/7A Samples from Depth $18.0 \mathrm{ft}$. to $495.0 \mathrm{ft}$.

SNL02030193001.019. Mechanical Properties Data for Drillhole USW NRG-7/7A Samples from Depth $507.4 \mathrm{ft}$. to 881.0-ft. Submittal date: 06/29/1994.

SNL02030193001.020. Mechanical Properties Data for Drillhole USW NRG-7/7A Samples from Depth $554.7 \mathrm{ft}$. to $1450.1-\mathrm{ft}$. Submittal date: 07/25/1994.

SNL02033084001.001. Matrix Compressive Tests of the Topopah Spring Member in USW G-2. Submittal date: 01/01/1988.

SNL02033084002.001. Parameter Effects on Matrix Compressive Properties of the Topopah Spring Member at Busted Butte. Submittal date: 08/28/1987.

SNL02040687003.001. Mechanical Property Data to Analyze the Response of Samples of Unit TSW2 to High Temperature and/or Low Strain Rates. Submittal date: 09/30/1992.

SNL02040687004.001. Creep in Topopah Spring Member Welded Tuff. Submittal date: $07 / 07 / 1998$.

SNL02062685001.001. Determinations of the Effect of Sample Size on the Mechanical Properties of the Welded Topopah Spring Member, Busted Butte. Submittal date: 09/09/1986.

SNL02071596001.001. Creep Properties of the Paintbrush Tuff Recovered From Borehole USW NRG-7/7a. Submittal Date: 10/01/1997.

SNL02072983001.001. Laboratory Comparison of Mechanical Compressive Data from Matrix Compressive Tests Using Busted Butte Outcrop Samples. Submittal date: 01/03/1985.

SNL02072983002.001. Laboratory Comparison of Mechanical Compressive Data from Matrix Compressive Tests Using Busted Butte Outcrop Samples. Submittal date: 01/03/1985.

SNL02072983003.001. Laboratory Comparison of Mechanical Compressive Data from Matrix Compressive Tests Using the Busted Butte Outcrop Samples. Submittal date: 01/03/1985.

SNL02100181001.001. Laboratory Comparison of Matrix Compressive Tests Using the Calico Hills Member in USW G-1. Submittal date: 05/01/1982.

SNL02120584001.001. Matrix Compressive Tests to Determine Parameter Effects. Submittal date: $06 / 01 / 1986$.

SNL04021384001.001. Characterization of Samples in Support of Mechanical Testing on Densely Welded Samples of the Topopah Spring Member from Busted Butte. Submittal date: $02 / 25 / 1987$.

SNL23100198001.001. Laboratory Testing of Concrete Properties at Elevated Temperatures (Including Aggregate Characterization). Submittal date: 12/22/1998. 
SNSAND86713000.000. Laboratory Determination of the Mechanical, Ultrasonic and Hydrologic Properties of Welded Tuff from the Grouse Canyon Heated Block Site. Submittal date: $08 / 01 / 1987$.

SNSAND92045000.000. Rock Mass Mechanical Property Estimations for the Yucca Mountain Site Characterization Project. Submittal date: 01/10/1994.

SNSAND95048800.000. Geotechnical Characterization of the North Ramp of the Exploratory Studies Facility, Volume I: Data Summary, and Volume II: NRG Corehole Data Appendices. Submittal date: 01/08/1996.

UN0109SPA024MT.001. Batch \#1 MTS Test Results for Titanium Grade 7 Under Low Strain Rate Tensile Testing. Submittal date: 09/21/2001.

UN0109SPA024MT.002. Batch \#2 MTS Test Results for Titanium Grade 7 Under Low Strain Rate Tensile Testing. Submittal date: 09/21/2001.

UN0109SPA024MT.003. Batch \#3 MTS Test Results for Titanium Grade 7 Under Low Strain Rate Tensile Testing. Submittal date: 09/21/2001.

UN0109SPA024MT.004. Batch \#4 Instron Dynatup Tensile Test Results for Titanium Grade 7 Under Impact Loading. Submittal date: 09/21/2001.

UN0109SPA024MT.005. Batch \#5 Instron Dynatup Tensile Test Results for Titanium Grade 7 Under Impact Loading. Submittal date: 09/21/2001.

UN0110SPA024MT.006. MTS Test Results for Steel 316L Under Low Strain Rate Tensile Testing (Batch \#1). Submittal date: 10/15/2001.

UN0110SPA024MT.007. MTS Tensile Test Results for Steel 316L Under High Strain Rate loading (Batch \#2). Submittal date: 10/15/2001.

UN0110SPA024MT.008. MTS Tensile Test Results of Steel 316L Under High Strain Rate Loading (Batch \#3). Submittal date: 10/15/2001.

UN0110SPA024MT.009. MTS Tensile Test Results of Alloy C22 Under Low Strain Rate Loading (Batch \#1). Submittal date: 10/16/2001.

UN0110SPA024MT.010. MTS Tensile Test Results of Alloy C22 Under High Strain Rate Loading (Batch \#2). Submittal date: 10/16/2001.

UN0110SPA024MT.011. MTS Tensile Test Results of Alloy C22 Under High Strain Rate Loading (Batch \#3). Submittal date: 10/16/2001.

UN0201SPA024MT.012. Instron Tensile Test Results for Alloy C22 Under Moderate Strain Rate (Batch \#4). Submittal date: 01/24/2002. 
UN0201SPA024MT.013. Instron Tensile Test Results for Alloy C22 Under Moderate Strain Rate (Batch \#5). Submittal date: 01/24/2002.

UN0201SPA024MT.014. Instron Tensile Test Results for Stainless Steel 316L Under Moderate Strain Rate Specimen 10S. Submittal date: 01/24/2002.

UN0201SPA024MT.015. Instron Tensile Test Results for Stainless Steel 316L Under Moderate Strain Rate, Specimen 12S. Submittal date: 01/24/2002.

UN0201SPA024MT.016. Instron Tensile Test Results for Stainless Steel 316L Under Moderate Strain Rate, Specimen 15S. Submittal date: 01/24/2002.

UN0201SPA024MT.017. Instron Tensile Test Results for Stainless Steel 316L Under Moderate Strain Rate, Specimen 20S. Submittal date: 01/24/2002.

UN0201SPA024MT.018. MTS Tensile Test Results for Alloy C22 Under Low Strain Rate (Batch \#6). Submittal date: 01/24/2002.

\subsection{OUTPUT DATA, LISTED BY DATA TRACKING NUMBER}

MO0306DQRIRPTS.002. Intact Rock Properties Data for Tensile Strength.

MO0306DQRIRPSH.001. Intact Rock Properties Data for Schmidt Rebound Hardness.

MO0306DQRIRPTC.001. Intact Rock Properties Data for Rock Triaxial Creep.

\subsection{SOFTWARE}

Only YMP standard software (MS Word and Excel) was used to generate the information contained in this technical report. 
Table 1. Disposition of DTNs Found Linked to Potentially Relevant Parameters

\begin{tabular}{|c|c|c|c|c|c|}
\hline DTN & TITLE & TYPE & $\begin{array}{c}\text { STATUS } \\
\text { (start } \\
\text { of review) }\end{array}$ & DISPOSITION & VERIFICATION \\
\hline GS920983114220.001 & $\begin{array}{l}\text { LOG OF TEST PIT OR AUGER HOLE, } \\
\text { PHYSICAL PROPERTIES SUMMARY, } \\
\text { GRADATION TEST, AND SUMMARY } \\
\text { OF PHYSICAL PROPERTIES TEST } \\
\text { RESULTS FOR HOLE NUMBERS } \\
\text { NRSF-TP-11, TP-19, TP-21, TP-25, } \\
\text { TP-28, TP-29, AND TP-30. }\end{array}$ & A & Q & \begin{tabular}{|l|} 
Repeats or \\
summarizes \\
values taken from \\
other sources \\
that were \\
evaluated, not \\
used..
\end{tabular} & $\begin{array}{l}\text { Requires } \\
\text { verification } \\
\text { and/or } \\
\text { qualification. }\end{array}$ \\
\hline GS920983114220.002 & $\begin{array}{l}\text { DRILL HOLE UE-25 NRG-1 ROCK } \\
\text { CORE TESTS. }\end{array}$ & A & Q & \begin{tabular}{l|} 
Repeats or \\
summarizes \\
values taken from \\
other sources \\
that were \\
evaluated, not \\
used.
\end{tabular} & $\begin{array}{l}\text { Requires } \\
\text { verification } \\
\text { and/or } \\
\text { qualification. }\end{array}$ \\
\hline GS921283114220.003 & $\begin{array}{l}\text { RELATIVE DENSITY } \\
\text { DETERMINATION, LAB TESTS OF } \\
\text { PHYSICAL PROPERTIES, NORTH } \\
\text { RAMP. }\end{array}$ & A & Q & \begin{tabular}{|l|} 
Material not \\
related to \\
property of \\
interest, not used.
\end{tabular} & $\begin{array}{l}\text { Requires } \\
\text { verification } \\
\text { and/or } \\
\text { qualification. }\end{array}$ \\
\hline GS921283114220.004 & $\begin{array}{l}\text { SUMMARY ACCESS ROAD TEST PIT } \\
\text { DATA, LOGS OF VISUAL } \\
\text { OBSERVATIONS OF SITE AND TEST } \\
\text { PIT. }\end{array}$ & A & Q & \begin{tabular}{|l|} 
Material not \\
related to \\
property of \\
interest, not used.
\end{tabular} & $\begin{array}{l}\text { Requires } \\
\text { verification } \\
\text { and/or } \\
\text { qualification. }\end{array}$ \\
\hline GS921283114220.005 & $\begin{array}{l}\text { PHYSICAL PROPERTIES AND } \\
\text { DIMENSIONAL TOLERANCE } \\
\text { CONFORMANCE OF ROCK CORE } \\
\text { TEST SPECIMENS. }\end{array}$ & A & Q & \begin{tabular}{|l|} 
Material not \\
related to \\
property of \\
interest, not used.
\end{tabular} & $\begin{array}{l}\text { Requires } \\
\text { verification } \\
\text { and/or } \\
\text { qualification. }\end{array}$ \\
\hline GS921283114220.006 & $\begin{array}{l}\text { PULSE VELOCITIES AND } \\
\text { ULTRASONIC ELASTIC CONSTANTS } \\
\text { OF INTACT ROCK CORE TEST } \\
\text { SPECIMENS. }\end{array}$ & A & Q & \begin{tabular}{|l|} 
Material not \\
related to \\
property of \\
interest, not used. \\
\end{tabular} & $\begin{array}{l}\text { Requires } \\
\text { verification } \\
\text { and/or } \\
\text { qualification. } \\
\end{array}$ \\
\hline GS921283114220.007 & $\begin{array}{l}\text { DIRECT SHEAR TESTS RESULTS - } \\
\text { INTACT ROCK AND SLIDING } \\
\text { FRICTION BOREHOLE UE-25 } \\
\text { NRG\#1. }\end{array}$ & A & Q & \begin{tabular}{|l|} 
Material not \\
related to \\
property of \\
interest, not used
\end{tabular} & $\begin{array}{l}\text { Requires } \\
\text { verification } \\
\text { and/or } \\
\text { qualification }\end{array}$ \\
\hline GS921283114220.010 & $\begin{array}{l}\text { SPLITTING TENSILE STRENGTH OF } \\
\text { INTACT ROCK CORE SPECIMENS } \\
\text { FROM UE-25 NRG\#1. }\end{array}$ & A & $Q$ & Directly used. & $\begin{array}{l}\text { Requires } \\
\text { verification } \\
\text { and/or } \\
\text { qualification. }\end{array}$ \\
\hline GS921283114220.014 & $\begin{array}{l}\text { SOIL AND ROCK GEOTECHNICAL } \\
\text { INVESTIGATIONS, FIELD AND } \\
\text { LABORATORY STUDIES, NORTH } \\
\text { RAMP SURFACE FACILITY, } \\
\text { EXPLORATORY STUDIES FACILITY, } \\
\text { YUCCA MOUNTAIN PROJECT. }\end{array}$ & D & Q & $\begin{array}{l}\text { No relevant data } \\
\text { presented or out } \\
\text { of area of } \\
\text { interest, not used. }\end{array}$ & $\begin{array}{l}\text { Requires } \\
\text { verification } \\
\text { and/or } \\
\text { qualification }\end{array}$ \\
\hline
\end{tabular}


Table 1. Disposition of DTNs Found Linked to Potentially Relevant Parameters (Continued)

\begin{tabular}{|c|c|c|c|c|c|}
\hline DTN & TITLE & TYPE & $\begin{array}{l}\text { STATUS } \\
\text { (start of } \\
\text { review) }\end{array}$ & DISPOSITION & VERIFICATION \\
\hline LL940800104244.000 & $\begin{array}{l}\text { COMPILATION OF INSULATING } \\
\text { MATERIAL PROPERTIES FOR USE } \\
\text { IN THE LARGE BLOCK TEST. }\end{array}$ & A & $U$ & $\begin{array}{l}\text { No relevant data } \\
\text { presented or out } \\
\text { of area of } \\
\text { interest, not used. }\end{array}$ & $\begin{array}{l}\text { Requires } \\
\text { verification } \\
\text { and/or } \\
\text { qualification. }\end{array}$ \\
\hline LL960905005911.010 & $\begin{array}{l}\text { ENGINEERED MATERIALS } \\
\text { CHARACTERIZATION REPORT FOR } \\
\text { THE YUCCA MOUNTAIN SITE } \\
\text { CHARACTERIZATION PROJECT. }\end{array}$ & A & $u$ & $\begin{array}{l}\text { No relevant data } \\
\text { presented or out } \\
\text { of area of } \\
\text { interest, not used }\end{array}$ & $\begin{array}{l}\text { Requires } \\
\text { verification and/ } \\
\text { or qualification. }\end{array}$ \\
\hline LL981112505924.050 & $\begin{array}{l}\text { STRESS CORROSION CRACKING } \\
\text { OF NI-BASE AND TI ALLOYS UNDER } \\
\text { CONTROLLED POTENTIAL. }\end{array}$ & A & $U$ & $\begin{array}{l}\text { No relevant data } \\
\text { presented or out } \\
\text { of area of } \\
\text { interest, not used. }\end{array}$ & $\begin{array}{l}\text { Requires } \\
\text { verification } \\
\text { and/or } \\
\text { qualification. }\end{array}$ \\
\hline |LL981212005924.062 & $\begin{array}{l}\text { DEGRADATION MODE SURVEY } \\
\text { CANDIDATE TITANIUM-BASE } \\
\text { ALLOYS FOR YUCCA MOUNTAIN } \\
\text { PROJECT WASTE PACKAGE } \\
\text { MATERIALS. }\end{array}$ & A & 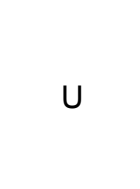 & $\begin{array}{l}\text { No relevant data } \\
\text { presented or out } \\
\text { of area of } \\
\text { interest, not used. }\end{array}$ & $\begin{array}{l}\text { Requires } \\
\text { verification } \\
\text { and/or } \\
\text { qualification }\end{array}$ \\
\hline LL990201804243.031 & $\begin{array}{l}\text { GEOMECHANICAL ANALYSIS OF } \\
\text { THE LARGE BLOCK TEST (MOL- } \\
\text { 236). VA SUPPORTING DATA. }\end{array}$ & D & U & $\begin{array}{l}\text { No relevant data } \\
\text { presented or out } \\
\text { of area of } \\
\text { interest, not used. }\end{array}$ & $\begin{array}{l}\text { Requires } \\
\text { verification } \\
\text { and/or } \\
\text { qualification }\end{array}$ \\
\hline |LL990704905924.085 & $\begin{array}{l}\text { CRACKING OF TITANIUM ALLOYS } \\
\text { UNDER CATHODIC APPLIED } \\
\text { ELECTROCHEMICAL POTENTIAL } \\
\text { TITANIUM GRADES } 7 \text { AND } 12 \text { WERE } \\
\text { PLACED IN AN AQUEOUS } \\
\text { ENVIRONMENT AND SUBJECTED } \\
\text { TO CHANGES IN CATHODIC } \\
\text { POTENTIAL. }\end{array}$ & A & Q & $\begin{array}{l}\text { No relevant data } \\
\text { presented or out } \\
\text { of area of } \\
\text { interest, not used. }\end{array}$ & $\begin{array}{l}\text { Requires } \\
\text { verification } \\
\text { and/or } \\
\text { qualification }\end{array}$ \\
\hline MO0001SEPSRMPC.000 & $\begin{array}{l}\text { SUMMARY OF ROCK MASS } \\
\text { PROPERTIES FOR CONFINING } \\
\text { STRESS RANGING FROM } 0 \text { TO } 42 \\
\text { MPa. }\end{array}$ & D & U & $\begin{array}{l}\text { No relevant data } \\
\text { presented or out } \\
\text { of area of } \\
\text { interest, not used }\end{array}$ & $\begin{array}{l}\text { Requires } \\
\text { verification } \\
\text { and/or } \\
\text { qualification. }\end{array}$ \\
\hline MO0003RIB00071.000 & $\begin{array}{l}\text { PHYSICAL AND CHEMICAL } \\
\text { CHARACTERISTICS OF ALLOY } 22\end{array}$ & D & Q & $\begin{array}{l}\text { Repeats or } \\
\text { summarizes } \\
\text { values taken from } \\
\text { other sources } \\
\text { that were } \\
\text { evaluated, not } \\
\text { used. }\end{array}$ & $\begin{array}{l}\text { Verified using } \\
\text { AP-3.15Q } \\
\text { Checklist for } \\
\text { Principle } \\
\text { Factors. }\end{array}$ \\
\hline
\end{tabular}


Table 1. Disposition of DTNs Found Linked to Potentially Relevant Parameters (Continued)

\begin{tabular}{|c|c|c|c|c|c|}
\hline DTN & TITLE & TYPE & $\begin{array}{l}\text { STATUS } \\
\text { (start of } \\
\text { review) }\end{array}$ & DISPOSITION & VERIFICATION \\
\hline MO0003RIB00072.000 & $\begin{array}{l}\text { PHYSICAL AND CHEMICAL } \\
\text { CHARACTERISTICS OF STEEL, } \\
\text { A } 516\end{array}$ & D & Q & $\begin{array}{l}\text { Repeats or } \\
\text { summarizes } \\
\text { values taken from } \\
\text { other sources } \\
\text { that were } \\
\text { evaluated, not } \\
\text { used. }\end{array}$ & $\begin{array}{l}\text { Developed } \\
\text { (acquired) } \\
\text { under PVAR } \\
\text { procedures or } \\
\text { expert elicitation } \\
\text { - No data } \\
\text { verification is } \\
\text { required }\end{array}$ \\
\hline MO0003RIB00073.000 & $\begin{array}{l}\text { PHYSICAL AND CHEMICAL } \\
\text { CHARACTERISTICS OF TI GRADES } \\
7 \text { AND } 16 .\end{array}$ & D & Q & $\begin{array}{l}\text { Repeats or } \\
\text { summarizes } \\
\text { values taken from } \\
\text { other sources } \\
\text { that were } \\
\text { evaluated, not } \\
\text { used. }\end{array}$ & $\begin{array}{l}\text { Developed } \\
\text { (acquired) } \\
\text { under PVAR } \\
\text { procedures or } \\
\text { expert elicitation } \\
\text { No data } \\
\text { verification is } \\
\text { required. }\end{array}$ \\
\hline MO0003RIB00076.000 & $\begin{array}{l}\text { PHYSICAL AND CHEMICAL } \\
\text { CHARACTERISTICS OF TYPE } 316 \mathrm{~N} \\
\text { GRADE }\end{array}$ & D & Q & $\begin{array}{l}\text { Repeats or } \\
\text { summarizes } \\
\text { values taken from } \\
\text { other sources } \\
\text { that were } \\
\text { evaluated, not } \\
\text { used. }\end{array}$ & $\begin{array}{l}\text { Verified using } \\
\text { AP-3.15Q } \\
\text { Checklist for } \\
\text { Principle } \\
\text { Factors }\end{array}$ \\
\hline MO0003RIB00079.000 & ROCK MECHANICAL PROPERTIES & D & $u$ & $\begin{array}{l}\text { Repeats or } \\
\text { summarizes } \\
\text { values taken from } \\
\text { other sources } \\
\text { that were } \\
\text { evaluated, not } \\
\text { used. }\end{array}$ & $\begin{array}{l}\text { Requires } \\
\text { verification } \\
\text { and/or } \\
\text { qualification. }\end{array}$ \\
\hline MO0109RIB00049.001 & $\begin{array}{l}\text { WASTE PACKAGE MATERIAL } \\
\text { PROPERTIES: NEUTRON } \\
\text { ABSORBING MATERIALS }\end{array}$ & D & Q & $\begin{array}{l}\text { Repeats or } \\
\text { summarizes } \\
\text { values taken from } \\
\text { other sources } \\
\text { that were } \\
\text { evaluated, not } \\
\text { used. }\end{array}$ & \begin{tabular}{|l|} 
Developed \\
(acquired) \\
under PVAR \\
procedures or \\
expert elicitation \\
No data \\
verification is \\
required.
\end{tabular} \\
\hline MO0204EBSPYMPG.017 & $\begin{array}{l}\text { PHYSICAL AND MECHANICAL } \\
\text { PROPERTIES OF GROUT }\end{array}$ & A & Q & $\begin{array}{l}\text { Material not } \\
\text { related to } \\
\text { property of } \\
\text { interest, not used. }\end{array}$ & \begin{tabular}{|l|} 
Developed \\
(acquired) \\
under PVAR \\
procedures or \\
expert elicitation \\
No data \\
verification is \\
required
\end{tabular} \\
\hline
\end{tabular}


Table 1. Disposition of DTNs Found Linked to Potentially Relevant Parameters (Continued)

\begin{tabular}{|c|c|c|c|c|c|}
\hline DTN & TITLE & TYPE & $\begin{array}{l}\text { STATUS } \\
\text { (start of } \\
\text { review) }\end{array}$ & DISPOSITION & VERIFICATION \\
\hline MO0204RIB00133.000 & $\begin{array}{l}\text { ROCK TENSILE STRENGTH } \\
\text { (BRAZILIAN METHOD) BASED ON } \\
\text { THE RESEARCH THAT HAS BEEN } \\
\text { ACCOMPLISHED BY THE } \\
\text { SUBSURFACE DESIGN } \\
\text { ORGANIZATION. }\end{array}$ & D & Q & \begin{tabular}{l|} 
Repeats or \\
summarizes \\
values taken from \\
other sources \\
that were \\
evaluated, not \\
used.
\end{tabular} & $\begin{array}{l}\text { Developed } \\
\text { (acquired) } \\
\text { under PVAR } \\
\text { procedures or } \\
\text { expert elicitation } \\
\text { No data } \\
\text { verification is } \\
\text { required }\end{array}$ \\
\hline MO0205UCC024KZ.019 & $\begin{array}{l}\text { RESULTS OF TENSILE TESTING OF } \\
\text { ALLOY C22 UNDER VARIOUS } \\
\text { STRAIN RATES }\end{array}$ & D & $\mathrm{U}$ & $\begin{array}{l}\text { Model } \\
\text { input/output, does } \\
\text { not contain } \\
\text { measured values, } \\
\text { not used. }\end{array}$ & $\begin{array}{l}\text { Requires } \\
\text { verification } \\
\text { and/or } \\
\text { qualification. }\end{array}$ \\
\hline MO0205UCC024KZ.020 & $\begin{array}{l}\text { RESULTS OF TENSILE TESTING OF } \\
\text { STAINLESS STEEL } 316 L \text { UNDER } \\
\text { VARIOUS STRAIN RATES. }\end{array}$ & D & $\mathrm{u}$ & $\begin{array}{l}\text { Model } \\
\text { input/output, does } \\
\text { not contain } \\
\text { measured values, } \\
\text { not used. }\end{array}$ & $\begin{array}{l}\text { Requires } \\
\text { verification } \\
\text { and/or } \\
\text { qualification. }\end{array}$ \\
\hline MO0205UCC024KZ.021 & $\begin{array}{l}\text { RESULTS OF TENSILE TESTING OF } \\
\text { TITANIUM ALLOY GRADE } 7 \text { UNDER } \\
\text { VARIOUS STRAIN RATES }\end{array}$ & D & $\mathrm{U}$ & $\begin{array}{l}\text { Model } \\
\text { input/output, does } \\
\text { not contain } \\
\text { measured values, } \\
\text { not used. }\end{array}$ & $\begin{array}{l}\text { Requires } \\
\text { verification } \\
\text { and/or } \\
\text { qualification. }\end{array}$ \\
\hline MO9808RIB00041.000 & $\begin{array}{l}\text { REFERENCE INFORMATION BASE } \\
\text { DATA ITEM: ROCK } \\
\text { GEOMECHANICAL PROPERTIES. }\end{array}$ & A & Q & $\begin{array}{l}\text { Superseded data, } \\
\text { not used. }\end{array}$ & $\begin{array}{l}\text { To be verified, } \\
\text { TBV\# } 3143\end{array}$ \\
\hline MO9906RIB00048.000 & $\begin{array}{l}\text { WASTE PACKAGE MATERIAL } \\
\text { PROPERTIES: WASTE FORM } \\
\text { MATERIALS. }\end{array}$ & D & Q & \begin{tabular}{|l|} 
Material not \\
related to \\
property of \\
interest, not used
\end{tabular} & $\begin{array}{l}\text { Requires } \\
\text { verification } \\
\text { and/or } \\
\text { qualification }\end{array}$ \\
\hline MO9906RIB00049.000 & $\begin{array}{l}\text { WASTE PACKAGE MATERIAL } \\
\text { PROPERTIES: NEUTRON } \\
\text { ABSORBING MATERIALS. }\end{array}$ & D & Q & $\begin{array}{l}\text { Superseded data, } \\
\text { not used. }\end{array}$ & $\begin{array}{l}\text { Requires } \\
\text { verification } \\
\text { and/or } \\
\text { qualification. }\end{array}$ \\
\hline MO9906RIB00050.000 & $\begin{array}{l}\text { WASTE PACKAGE MATERIAL } \\
\text { PROPERTIES: CERAMIC COATING } \\
\text { MATERIALS. }\end{array}$ & D & Q & \begin{tabular}{|l|} 
Material not \\
related to \\
property of \\
interest, not used.
\end{tabular} & $\begin{array}{l}\text { Requires } \\
\text { verification } \\
\text { and/or } \\
\text { qualification. }\end{array}$ \\
\hline MO9906RIB00052.000 & $\begin{array}{l}\text { WASTE PACKAGE MATERIAL } \\
\text { PROPERTIES: CORROSION } \\
\text { RESISTANT MATERIALS. }\end{array}$ & D & Q & \begin{tabular}{|l|} 
Material not \\
related to \\
property of \\
interest, not used.
\end{tabular} & $\begin{array}{l}\text { Requires } \\
\text { verification } \\
\text { and/or } \\
\text { qualification. }\end{array}$ \\
\hline MO9906RIB00053.000 & $\begin{array}{l}\text { WASTE PACKAGE MATERIALS: } \\
\text { CORROSION ALLOWANCE AND } \\
\text { BASKET MATERIALS }\end{array}$ & $\mathrm{D}$ & Q & $\begin{array}{l}\text { Material not } \\
\text { related to } \\
\text { property of } \\
\text { interest, not used. }\end{array}$ & $\begin{array}{l}\text { Requires } \\
\text { verification } \\
\text { and/or } \\
\text { qualification }\end{array}$ \\
\hline
\end{tabular}


Table 1. Disposition of DTNs Found Linked to Potentially Relevant Parameters (Continued)

\begin{tabular}{|c|c|c|c|c|c|}
\hline DTN & TITLE & TYPE & $\begin{array}{l}\text { STATUS } \\
\text { (start of } \\
\text { review) }\end{array}$ & DISPOSITION & VERIFICATION \\
\hline MO9906RIB00054.000 & $\begin{array}{l}\text { WASTE PACKAGE MATERIAL } \\
\text { PROPERTIES: STRUCTURAL } \\
\text { MATERIALS. }\end{array}$ & D & Q & $\begin{array}{l}\text { Material not } \\
\text { related to } \\
\text { property of } \\
\text { interest, not used. }\end{array}$ & $\begin{array}{l}\text { Requires } \\
\text { verification for } \\
\text { use with } \\
\text { principle factors }\end{array}$ \\
\hline MO9911SEPGRP34.000 & $\begin{array}{l}\text { GEOTECHNICAL ROCK } \\
\text { PROPERTIES }\end{array}$ & D & Q & $\begin{array}{l}\text { Material not } \\
\text { related to } \\
\text { property of } \\
\text { interest, not used }\end{array}$ & $\begin{array}{l}\text { Requires } \\
\text { verification for } \\
\text { use with } \\
\text { principle factors }\end{array}$ \\
\hline SNL02000000011.000 & $\begin{array}{l}\text { MATRIX COMPRESSIVE TESTS OF } \\
\text { THE TOPOPAH SPRING MEMBER IN } \\
\text { USW GU-3. }\end{array}$ & A & $\mathrm{U}$ & $\begin{array}{l}\text { No relevant data } \\
\text { presented or out } \\
\text { of area of } \\
\text { interest, not used. }\end{array}$ & $\begin{array}{l}\text { Requires } \\
\text { verification } \\
\text { and/or } \\
\text { qualification }\end{array}$ \\
\hline SNL02000000012.000 & $\begin{array}{l}\text { UNIAXIAL AND TRIAXIAL } \\
\text { COMPRESSION TEST SERIES ON } \\
\text { TOPOPAH SPRING TUFF. }\end{array}$ & A & $u$ & $\begin{array}{l}\text { No relevant data } \\
\text { presented or out } \\
\text { of area of } \\
\text { interest, not used }\end{array}$ & $\begin{array}{l}\text { Requires } \\
\text { verification } \\
\text { and/or } \\
\text { qualification }\end{array}$ \\
\hline SNL02030180001.001 & $\begin{array}{l}\text { MATRIX COMPRESSIVE TESTS TO } \\
\text { CHARACTERIZE TUFFS FROM UE- } \\
\text { 25A\#1 AND THE LASER DRIFT IN G- } \\
\text { TUNNEL. }\end{array}$ & A & $u$ & $\begin{array}{l}\text { No relevant data } \\
\text { presented or out } \\
\text { of area of } \\
\text { interest, not used. }\end{array}$ & $\begin{array}{l}\text { Requires } \\
\text { verification } \\
\text { and/or } \\
\text { qualification. }\end{array}$ \\
\hline SNL02030193001.002 & $\begin{array}{l}\text { MECHANICAL PROPERTIES DATA } \\
\text { FOR DRILL HOLE USW NRG-6 } \\
\text { SAMPLES FROM DEPTH } 22.2 \text { FT TO } \\
\text { 427.0 FT. }\end{array}$ & A & Q & Directly used & $\begin{array}{l}\text { Requires } \\
\text { verification } \\
\text { and/or } \\
\text { qualification. }\end{array}$ \\
\hline SNL02030193001.003 & $\begin{array}{l}\text { MECHANICAL PROPERTIES DATA } \\
\text { FOR DRILL HOLE UE-25 NRG\#2 } \\
\text { SAMPLES FROM DEPTH } 150.4 \text { FT } \\
\text { TO } 200.0 \text { FT. }\end{array}$ & A & Q & Directly used & $\begin{array}{l}\text { Requires } \\
\text { verification } \\
\text { and/or } \\
\text { qualification. }\end{array}$ \\
\hline SNL02030193001.005 & $\begin{array}{l}\text { MECHANICAL PROPERTIES DATA } \\
\text { FOR DRILL HOLE UE-25 NRG\#3 } \\
\text { SAMPLES FROM DEPTH 15.4 FT TO } \\
\text { 297.1 FT. }\end{array}$ & A & Q & Directly used & $\begin{array}{l}\text { Requires } \\
\text { verification } \\
\text { and/or } \\
\text { qualification. }\end{array}$ \\
\hline SNL02030193001.004 & $\begin{array}{l}\text { MECHANICAL PROPERTIES DATA } \\
\text { FOR DRILL HOLE USW-NRG-6 } \\
\text { SAMPLES FROM DEPTH } 462.3 \text { FT to } \\
\text { 1,085 FT. }\end{array}$ & A & Q & Directly used & $\begin{array}{l}\text { Requires } \\
\text { verification } \\
\text { and/or } \\
\text { qualification }\end{array}$ \\
\hline SNL02030193001.006 & $\begin{array}{l}\text { MECHANICAL PROPERTIES DATA } \\
\text { FOR DRILL HOLE UE-25 NRG\#2A } \\
\text { SAMPLES FROM DEPTH 90.0 FT TO } \\
\text { 254.5 FT. }\end{array}$ & A & Q & Directly used & $\begin{array}{l}\text { Requires } \\
\text { verification } \\
\text { and/or } \\
\text { qualification }\end{array}$ \\
\hline SNL02030193001.009 & $\begin{array}{l}\text { MECHANICAL PROPERTIES DATA } \\
\text { FOR DRILL HOLE UE25 NRG-5 } \\
\text { SAMPLES FROM DEPTH } 781.0 \text { FT } \\
\text { TO } 991.9 \text { FT. }\end{array}$ & A & Q & Directly used & $\begin{array}{l}\text { Requires } \\
\text { verification } \\
\text { and/or } \\
\text { qualification. }\end{array}$ \\
\hline SNL02030193001.013 & $\begin{array}{l}\text { MECHANICAL PROPERTIES DATA } \\
\text { FOR DRILL HOLE UE25 NRG-2B } \\
\text { SAMPLES FROM DEPTH } 2.7 \text { FT TO } \\
\text { 87.6 FT. }\end{array}$ & A & Q & Directly used & $\begin{array}{l}\text { Requires } \\
\text { verification } \\
\text { and/or } \\
\text { qualification. }\end{array}$ \\
\hline
\end{tabular}


Table 1. Disposition of DTNs Found Linked to Potentially Relevant Parameters (Continued)

\begin{tabular}{|c|c|c|c|c|c|}
\hline DTN & TITLE & TYPE & $\begin{array}{l}\text { STATUS } \\
\text { (start of } \\
\text { review) }\end{array}$ & DISPOSITION & VERIFICATION \\
\hline SNL02030193001.014 & $\begin{array}{l}\text { MECHANICAL PROPERTIES DATA } \\
\text { FOR DRILL HOLE UE25 NRG-4 } \\
\text { SAMPLES FROM DEPTH } 378.1 \text { FT } \\
\text { TO 695.8 FT. }\end{array}$ & A & Q & Directly used & $\begin{array}{l}\text { Requires } \\
\text { verification } \\
\text { and/or } \\
\text { qualification }\end{array}$ \\
\hline SNL02030193001.017 & $\begin{array}{l}\text { MECHANICAL PROPERTIES DATA } \\
\text { FOR DRILL HOLE UE25 NRG-4 } \\
\text { SAMPLES FROM DEPTH 18.0 FT TO } \\
\text { 495.0 FT. TENSILE STRENGTH, } \\
\text { AVERAGE GRAIN DENSITY, \& } \\
\text { POROSITY. }\end{array}$ & A & Q & Directly used & $\begin{array}{l}\text { Requires } \\
\text { verification } \\
\text { and/or } \\
\text { qualification }\end{array}$ \\
\hline SNL02030193001.019 & $\begin{array}{l}\text { MECHANICAL PROPERTIES DATA } \\
\text { FOR DRILL HOLE USW NRG-7/7A } \\
\text { SAMPLES FROM DEPTH 507.4 FT } \\
\text { TO 881.0 FT. }\end{array}$ & A & Q & Directly used & $\begin{array}{l}\text { Verified using } \\
\text { AP-3.15Q } \\
\text { Checklist for } \\
\text { Principle } \\
\text { Factors. }\end{array}$ \\
\hline SNL02030193001.020 & $\begin{array}{l}\text { MECHANICAL PROPERTIES DATA } \\
\text { FOR DRILL HOLE USW NRG-7/7A } \\
\text { SAMPLES FROM DEPTH 554.7 FT } \\
\text { TO 1450.1 FT. }\end{array}$ & A & Q & Directly used & $\begin{array}{l}\text { Verified using } \\
\text { AP-3.15Q } \\
\text { Checklist for } \\
\text { Principle } \\
\text { Factors } \\
\end{array}$ \\
\hline SNL02033084001.001 & $\begin{array}{l}\text { MATRIX COMPRESSIVE TESTS OF } \\
\text { THE TOPOPAH SPRING MEMBER IN } \\
\text { USW G-2. }\end{array}$ & A & U & $\begin{array}{l}\text { No relevant data } \\
\text { presented or out } \\
\text { of area of } \\
\text { interest, not used. }\end{array}$ & $\begin{array}{l}\text { Requires } \\
\text { verification } \\
\text { and/or } \\
\text { qualification. }\end{array}$ \\
\hline SNL02033084002.001 & $\begin{array}{l}\text { PARAMETER EFFECTS ON MATRIX } \\
\text { COMPRESSIVE PROPERTIES OF } \\
\text { THE TOPOPAH SPRING MEMBER } \\
\text { AT BUSTED BUTTE. }\end{array}$ & A & $\mathrm{U}$ & $\begin{array}{l}\text { No relevant data } \\
\text { presented or out } \\
\text { of area of } \\
\text { interest, not used }\end{array}$ & $\begin{array}{l}\text { Requires } \\
\text { verification } \\
\text { and/or } \\
\text { qualification. }\end{array}$ \\
\hline SNL02040687003.001 & $\begin{array}{l}\text { MECHANICAL PROPERTY DATA TO } \\
\text { ANALYZE THE RESPONSE OF } \\
\text { SAMPLES OF UNIT TSW2 TO HIGH } \\
\text { TEMPERATURE AND/OR LOW } \\
\text { STRAIN RATES }\end{array}$ & A & $\mathrm{U}$ & $\begin{array}{l}\text { No relevant data } \\
\text { presented or out } \\
\text { of area of } \\
\text { interest, not used. }\end{array}$ & $\begin{array}{l}\text { Requires } \\
\text { verification } \\
\text { and/or } \\
\text { qualification. }\end{array}$ \\
\hline SNL02040687004.001 & $\begin{array}{l}\text { CREEP IN TOPOPAH SPRING } \\
\text { MEMBER WELDED TUFF }\end{array}$ & A & Q & $\begin{array}{l}\text { No relevant data } \\
\text { presented, } \\
\text { related report } \\
\text { contains data but } \\
\text { not the DTN, not } \\
\text { used. }\end{array}$ & $\begin{array}{l}\text { Requires } \\
\text { verification and/ } \\
\text { or qualification. }\end{array}$ \\
\hline SNL02062685001.001 & $\begin{array}{l}\text { DETERMINATIONS OF THE EFFECT } \\
\text { OF SAMPLE SIZE ON THE } \\
\text { MECHANICAL PROPERTIES OF THE } \\
\text { WELDED TOPOPAH SPRING } \\
\text { MEMBER, BUSTED BUTTE. }\end{array}$ & A & 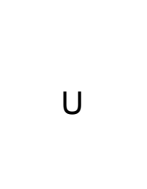 & $\begin{array}{l}\text { No relevant data } \\
\text { presented or out } \\
\text { of area of } \\
\text { interest, not used. }\end{array}$ & $\begin{array}{l}\text { Requires } \\
\text { verification } \\
\text { and/or } \\
\text { qualification. }\end{array}$ \\
\hline
\end{tabular}


Table 1. Disposition of DTNs Found Linked to Potentially Relevant Parameters (Continued)

\begin{tabular}{|c|c|c|c|c|c|}
\hline DTN & TITLE & TYPE & $\begin{array}{l}\text { STATUS } \\
\text { (start of } \\
\text { review) }\end{array}$ & DISPOSITION & VERIFICATION \\
\hline SNL02071596001.001 & $\begin{array}{l}\text { CREEP PROPERTIES OF THE } \\
\text { PAINTBRUSH TUFF RECOVERED } \\
\text { FROM BOREHOLE USW NRG-7/7A: } \\
\text { DATA REPORT. }\end{array}$ & A & Q & Directly used & $\begin{array}{l}\text { Requires } \\
\text { verification and/ } \\
\text { or qualification }\end{array}$ \\
\hline SNL02072983001.001 & $\begin{array}{l}\text { LABORATORY COMPARISON OF } \\
\text { MECHANICAL COMPRESSIVE DATA } \\
\text { FROM MATRIX COMPRESSIVE } \\
\text { TESTS USING BUSTED BUTTE } \\
\text { OUTCROP SAMPLES. }\end{array}$ & A & $U$ & $\begin{array}{l}\text { No relevant data } \\
\text { presented or out } \\
\text { of area of } \\
\text { interest, not used. }\end{array}$ & $\begin{array}{l}\text { Requires } \\
\text { verification } \\
\text { and/or } \\
\text { qualification. }\end{array}$ \\
\hline SNL02072983002.001 & $\begin{array}{l}\text { LABORATORY COMPARISON OF } \\
\text { MECHANICAL COMPRESSIVE DATA } \\
\text { FROM MATRIX COMPRESSIVE } \\
\text { TESTS USING BUSTED BUTTE } \\
\text { OUTCROP SAMPLES. }\end{array}$ & A & $U$ & $\begin{array}{l}\text { No relevant data } \\
\text { presented or out } \\
\text { of area of } \\
\text { interest, not used. }\end{array}$ & $\begin{array}{l}\text { Requires } \\
\text { verification } \\
\text { and/or } \\
\text { qualification. }\end{array}$ \\
\hline SNL02072983003.001 & $\begin{array}{l}\text { LABORATORY COMPARISON OF } \\
\text { MECHANICAL COMPRESSIVE DATA } \\
\text { FROM MATRIX COMPRESSIVE } \\
\text { TESTS USING THE BUSTED BUTTE } \\
\text { OUTCROP SAMPLES. }\end{array}$ & A & U & $\begin{array}{l}\text { No relevant data } \\
\text { presented or out } \\
\text { of area of } \\
\text { interest, not used. }\end{array}$ & $\begin{array}{l}\text { Requires } \\
\text { verification } \\
\text { and/or } \\
\text { qualification. }\end{array}$ \\
\hline SNL02100181001.001 & $\begin{array}{l}\text { LABORATORY COMPARISON OF } \\
\text { MATRIX COMPRESSIVE TESTS } \\
\text { USING THE CALICO HILLS MEMBER } \\
\text { IN USW G-1. }\end{array}$ & A & $U$ & $\begin{array}{l}\text { No relevant data } \\
\text { presented or out } \\
\text { of area of } \\
\text { interest, not used. }\end{array}$ & $\begin{array}{l}\text { Requires } \\
\text { verification } \\
\text { and/or } \\
\text { qualification. }\end{array}$ \\
\hline SNL02120584001.001 & $\begin{array}{l}\text { MATRIX COMPRESSIVE TESTS TO } \\
\text { DETERMINE PARAMETER } \\
\text { EFFECTS. }\end{array}$ & A & $U$ & $\begin{array}{l}\text { No relevant data } \\
\text { presented or out } \\
\text { of area of } \\
\text { interest, not used. }\end{array}$ & $\begin{array}{l}\text { Requires } \\
\text { verification } \\
\text { and/or } \\
\text { qualification. }\end{array}$ \\
\hline SNL04021384001.001 & $\begin{array}{l}\text { CHARACTERIZATION OF SAMPLES } \\
\text { IN SUPPORT OF MECHANICAL } \\
\text { TESTING ON DENSELY WELDED } \\
\text { SAMPLES OF THE TOPOPAH } \\
\text { SPRING MEMBER FROM BUSTED } \\
\text { BUTTE. }\end{array}$ & A & $\mathrm{U}$ & $\begin{array}{l}\text { No relevant data } \\
\text { presented or out } \\
\text { of area of } \\
\text { interest, not used. }\end{array}$ & $\begin{array}{l}\text { Requires } \\
\text { verification } \\
\text { and/or } \\
\text { qualification. }\end{array}$ \\
\hline SNL23100198001.001 & $\begin{array}{l}\text { LABORATORY TESTING OF } \\
\text { CONCRETE PROPERTIES AT } \\
\text { ELEVATED TEMPERATURES } \\
\text { (INCLUDING AGGREGATE } \\
\text { CHARACTERIZATION). }\end{array}$ & A & Q & $\begin{array}{l}\text { Material not } \\
\text { related to } \\
\text { property of } \\
\text { interest, not used. }\end{array}$ & $\begin{array}{l}\text { Requires } \\
\text { verification } \\
\text { and/or } \\
\text { qualification. }\end{array}$ \\
\hline SNSAND86713000.000 & $\begin{array}{l}\text { LABORATORY DETERMINATION OF } \\
\text { THE MECHANICAL, ULTRASONIC } \\
\text { AND HYDROLOGIC PROPERTIES } \\
\text { OF WELDED TUFF FROM THE } \\
\text { GROUSE CANYON HEATED BLOCK } \\
\text { SITE. }\end{array}$ & $\mathrm{D}$ & $U$ & $\begin{array}{l}\text { No relevant data } \\
\text { presented or out } \\
\text { of area of } \\
\text { interest, not used. }\end{array}$ & $\begin{array}{l}\text { Requires } \\
\text { verification } \\
\text { and/or } \\
\text { qualification. }\end{array}$ \\
\hline SNSAND92045000.000 & $\begin{array}{l}\text { ROCK MASS MECHANICAL } \\
\text { PROPERTY ESTIMATIONS FOR THE } \\
\text { YUCCA MOUNTAIN SITE } \\
\text { CHARACTERIZATION PROJECT. }\end{array}$ & $\mathrm{D}$ & $U$ & $\begin{array}{l}\text { No relevant data } \\
\text { presented or out } \\
\text { of area of } \\
\text { interest, not used. }\end{array}$ & $\begin{array}{l}\text { Requires } \\
\text { verification } \\
\text { and/or } \\
\text { qualification. }\end{array}$ \\
\hline
\end{tabular}


Table 1. Disposition of DTNs Found Linked to Potentially Relevant Parameters (Continued)

\begin{tabular}{|c|c|c|c|c|c|}
\hline DTN & TITLE & TYPE & $\begin{array}{l}\text { STATUS } \\
\text { (start of } \\
\text { review) }\end{array}$ & DISPOSITION & VERIFICATION \\
\hline UN0109SPA024MT.001 & $\begin{array}{l}\text { BATCH \#1 MTS TEST RESULTS FOR } \\
\text { TITANIUM GRADE } 7 \text { UNDER LOW } \\
\text { STRAIN RATE TENSILE TESTING }\end{array}$ & A & Q & $\begin{array}{l}\text { Material not } \\
\text { related to } \\
\text { property of } \\
\text { interest, not used. }\end{array}$ & $\begin{array}{l}\text { Developed } \\
\text { (acquired) } \\
\text { under PVAR } \\
\text { procedures or } \\
\text { expert elicitation } \\
\text { No data } \\
\text { verification is } \\
\text { required. }\end{array}$ \\
\hline UN0109SPA024MT.002 & $\begin{array}{l}\text { BATCH \#2 MTS TEST RESULTS FOR } \\
\text { TITANIUM GRADE } 7 \text { UNDER LOW } \\
\text { STRAIN RATE TENSILE TESTING. }\end{array}$ & A & Q & $\begin{array}{l}\text { Material not } \\
\text { related to } \\
\text { property of } \\
\text { interest, not used. }\end{array}$ & $\begin{array}{l}\text { Developed } \\
\text { (acquired) } \\
\text { under PVAR } \\
\text { procedures or } \\
\text { expert elicitation } \\
\text { No data } \\
\text { verification is } \\
\text { required } \\
\end{array}$ \\
\hline UN0109SPA024MT.003 & $\begin{array}{l}\text { BATCH \#3 MTS TEST RESULTS FOR } \\
\text { TITANIUM GRADE } 7 \text { UNDER LOW } \\
\text { STRAIN RATE TENSILE TESTING. }\end{array}$ & A & Q & $\begin{array}{l}\text { Material not } \\
\text { related to } \\
\text { property of } \\
\text { interest, not used. }\end{array}$ & $\begin{array}{l}\text { Developed } \\
\text { (acquired) } \\
\text { under PVAR } \\
\text { procedures or } \\
\text { expert elicitation } \\
\text { No data } \\
\text { verification is } \\
\text { required }\end{array}$ \\
\hline UN0109SPA024MT.004 & $\begin{array}{l}\text { BATCH \#4 INSTRON DYNATUP } \\
\text { TENSILE TEST RESULTS FOR } \\
\text { TITANIUM GRADE } 7 \text { UNDER IMPACT } \\
\text { LOADING }\end{array}$ & A & Q & $\begin{array}{l}\text { Material not } \\
\text { related to } \\
\text { property of } \\
\text { interest, not used. }\end{array}$ & $\begin{array}{l}\text { Developed } \\
\text { (acquired) } \\
\text { under PVAR } \\
\text { procedures or } \\
\text { expert elicitation } \\
\text { No data } \\
\text { verification is } \\
\text { required }\end{array}$ \\
\hline UN0109SPA024MT.005 & $\begin{array}{l}\text { BATCH \#5 INSTRON DYNATUP } \\
\text { TENSILE TEST RESULTS FOR } \\
\text { TITANIUM GRADE } 7 \text { UNDER IMPACT } \\
\text { LOADING }\end{array}$ & A & Q & $\begin{array}{l}\text { Material not } \\
\text { related to } \\
\text { property of } \\
\text { interest, not used. }\end{array}$ & $\begin{array}{l}\text { Developed } \\
\text { (acquired) } \\
\text { under PVAR } \\
\text { procedures or } \\
\text { expert elicitation } \\
\text { No data } \\
\text { verification is } \\
\text { required } \\
\end{array}$ \\
\hline UN0110SPA024MT.006 & $\begin{array}{l}\text { MTS TEST RESULTS FOR STEEL } \\
316 \text { L UNDER LOW STRAIN RATE } \\
\text { TENSILE TESTING (BATCH \#1) }\end{array}$ & A & Q & $\begin{array}{l}\text { Material not } \\
\text { related to } \\
\text { property of } \\
\text { interest, not used. }\end{array}$ & $\begin{array}{l}\text { Developed } \\
\text { (acquired) } \\
\text { under PVAR } \\
\text { procedures or } \\
\text { expert elicitation } \\
\text { No data } \\
\text { verification is } \\
\text { required }\end{array}$ \\
\hline
\end{tabular}


Table 1. Disposition of DTNs Found Linked to Potentially Relevant Parameters (Continued)

\begin{tabular}{|c|c|c|c|c|c|}
\hline DTN & TITLE & TYPE & $\begin{array}{l}\text { STATUS } \\
\text { (start of } \\
\text { review) }\end{array}$ & DISPOSITION & VERIFICATION \\
\hline UN0110SPA024MT.007 & $\begin{array}{l}\text { MTS TENSILE TEST RESULTS FOR } \\
\text { STEEL 316L UNDER HIGH STRAIN } \\
\text { RATE LOADING (BATCH \#2) }\end{array}$ & A & Q & $\begin{array}{l}\text { Material not } \\
\text { related to } \\
\text { property of } \\
\text { interest, not used. }\end{array}$ & $\begin{array}{l}\text { Developed } \\
\text { (acquired) } \\
\text { under PVAR } \\
\text { procedures or } \\
\text { expert elicitation } \\
\text { No data } \\
\text { verification is } \\
\text { required }\end{array}$ \\
\hline UN0110SPA024MT.008 & $\begin{array}{l}\text { MTS TENSILE TEST RESULTS OF } \\
\text { STEEL 316L UNDER HIGH STRAIN } \\
\text { RATE LOADING (BATCH \#3) }\end{array}$ & A & Q & $\begin{array}{l}\text { Material not } \\
\text { related to } \\
\text { property of } \\
\text { interest, not used. }\end{array}$ & $\begin{array}{l}\text { Developed } \\
\text { (acquired) } \\
\text { under PVAR } \\
\text { procedures or } \\
\text { expert elicitation } \\
\text { No data } \\
\text { verification is } \\
\text { required } \\
\end{array}$ \\
\hline UN0110SPA024MT.009 & $\begin{array}{l}\text { MTS TENSILE TEST RESULTS OF } \\
\text { ALLOY C22 UNDER LOW STRAIN } \\
\text { RATE LOADING (BATCH \#1) }\end{array}$ & A & Q & $\begin{array}{l}\text { Material not } \\
\text { related to } \\
\text { property of } \\
\text { interest, not used. }\end{array}$ & $\begin{array}{l}\text { Developed } \\
\text { (acquired) } \\
\text { under PVAR } \\
\text { procedures or } \\
\text { expert elicitation } \\
\text { No data } \\
\text { verification is } \\
\text { required }\end{array}$ \\
\hline UN0110SPA024MT.010 & $\begin{array}{l}\text { MTS TENSILE TEST RESULTS OF } \\
\text { ALLOY C22 UNDER HIGH STRAIN } \\
\text { RATE LOADING (BATCH \#2) }\end{array}$ & A & Q & $\begin{array}{l}\text { Material not } \\
\text { related to } \\
\text { property of } \\
\text { interest, not used. }\end{array}$ & $\begin{array}{l}\text { Developed } \\
\text { (acquired) } \\
\text { under PVAR } \\
\text { procedures or } \\
\text { expert elicitation } \\
\text { No data } \\
\text { verification is } \\
\text { required }\end{array}$ \\
\hline UN0110SPA024MT.011 & $\begin{array}{l}\text { MTS TENSILE TEST RESULTS OF } \\
\text { ALLOY C22 UNDER HIGH STRAIN } \\
\text { RATE LOADING (BATCH \#3) }\end{array}$ & A & Q & $\begin{array}{l}\text { Material not } \\
\text { related to } \\
\text { property of } \\
\text { interest, not used. }\end{array}$ & $\begin{array}{l}\text { Developed } \\
\text { (acquired) } \\
\text { under PVAR } \\
\text { procedures or } \\
\text { expert elicitation } \\
\text { No data } \\
\text { verification is } \\
\text { required } \\
\end{array}$ \\
\hline UN0201SPA024MT.012 & $\begin{array}{l}\text { INSTRON TENSILE TEST RESULTS } \\
\text { FOR ALLOY C22 UNDER } \\
\text { MODERATE STRAIN RATE (BATCH } \\
\text { \#4) }\end{array}$ & A & Q & $\begin{array}{l}\text { Material not } \\
\text { related to } \\
\text { property of } \\
\text { interest, not used. }\end{array}$ & $\begin{array}{l}\text { Developed } \\
\text { (acquired) } \\
\text { under PVAR } \\
\text { procedures or } \\
\text { expert elicitation } \\
\text { No data } \\
\text { verification is } \\
\text { required }\end{array}$ \\
\hline
\end{tabular}


Table 1. Disposition of DTNs Found Linked to Potentially Relevant Parameters (Continued)

\begin{tabular}{|c|c|c|c|c|c|}
\hline DTN & TITLE & TYPE & $\begin{array}{l}\text { STATUS } \\
\text { (start of } \\
\text { review) }\end{array}$ & DISPOSITION & VERIFICATION \\
\hline UN0201SPA024MT.013 & $\begin{array}{l}\text { INSTRON TENSILE TEST RESULTS } \\
\text { FOR ALLOY C22 UNDER } \\
\text { MODERATE STRAIN RATE (BATCH } \\
\text { \#5) }\end{array}$ & A & Q & $\begin{array}{l}\text { Material not } \\
\text { related to } \\
\text { property of } \\
\text { interest, not used. }\end{array}$ & $\begin{array}{l}\text { Developed } \\
\text { (acquired) } \\
\text { under PVAR } \\
\text { procedures or } \\
\text { expert elicitation } \\
\text { No data } \\
\text { verification is } \\
\text { required. }\end{array}$ \\
\hline UN0201SPA024MT.014 & $\begin{array}{l}\text { INSTRON TENSILE TEST RESULTS } \\
\text { FOR STAINLESS STEEL } 316 L \\
\text { UNDER MODERATE STRAIN RATE, } \\
\text { SPECIMEN 10S }\end{array}$ & A & Q & \begin{tabular}{|l|} 
Material not \\
related to \\
property of \\
interest, not used.
\end{tabular} & $\begin{array}{l}\text { Developed } \\
\text { (acquired) } \\
\text { under PVAR } \\
\text { procedures or } \\
\text { expert elicitation } \\
\text { No data } \\
\text { verification is } \\
\text { required. }\end{array}$ \\
\hline UN0201SPA024MT.015 & $\begin{array}{l}\text { INSTRON TENSILE TEST RESULTS } \\
\text { FOR STAINLESS STEEL } 316 L \\
\text { UNDER MODERATE STRAIN RATE, } \\
\text { SPECIMEN 12S }\end{array}$ & A & Q & $\begin{array}{l}\text { Material not } \\
\text { related to } \\
\text { property of } \\
\text { interest, not used. }\end{array}$ & $\begin{array}{l}\text { Developed } \\
\text { (acquired) } \\
\text { under PVAR } \\
\text { procedures or } \\
\text { expert elicitation } \\
\text { No data } \\
\text { verification is } \\
\text { required. }\end{array}$ \\
\hline UN0201SPA024MT.016 & $\begin{array}{l}\text { INSTRON TENSILE TEST RESULTS } \\
\text { FOR STAINLESS STEEL } 316 L \\
\text { UNDER MODERATE STRAIN RATE, } \\
\text { SPECIMEN 15S. }\end{array}$ & A & Q & $\begin{array}{l}\text { Material not } \\
\text { related to } \\
\text { property of } \\
\text { interest, not used. }\end{array}$ & $\begin{array}{l}\text { Developed } \\
\text { (acquired) } \\
\text { under PVAR } \\
\text { procedures or } \\
\text { expert elicitation } \\
\text { No data } \\
\text { verification is } \\
\text { required. }\end{array}$ \\
\hline UN0201SPA024MT.017 & $\begin{array}{l}\text { INSTRON TENSILE TEST RESULTS } \\
\text { FOR STAINLESS STEEL } 316 L \\
\text { UNDER MODERATE STRAIN RATE, } \\
\text { SPECIMEN 20S. }\end{array}$ & A & $Q$ & $\begin{array}{l}\text { Material not } \\
\text { related to } \\
\text { property of } \\
\text { interest, not used. }\end{array}$ & $\begin{array}{l}\text { Developed } \\
\text { (acquired) } \\
\text { under PVAR } \\
\text { procedures or } \\
\text { expert elicitation } \\
\text { No data } \\
\text { verification is } \\
\text { required. } \\
\end{array}$ \\
\hline |UN0201SPA024MT.018 & $\begin{array}{l}\text { MTS TENSILE TEST RESULTS FOR } \\
\text { ALLOY C22 UNDER LOW STRAIN } \\
\text { RATE (BATCH \#6) }\end{array}$ & A & Q & $\begin{array}{l}\text { Material not } \\
\text { related to } \\
\text { property of } \\
\text { interest, not used. }\end{array}$ & $\begin{array}{l}\text { Developed } \\
\text { (acquired) } \\
\text { under PVAR } \\
\text { procedures or } \\
\text { expert elicitation } \\
\text { No data } \\
\text { verification is } \\
\text { required }\end{array}$ \\
\hline
\end{tabular}


Table 1. Disposition of DTNs Found Linked to Potentially Relevant Parameters (Continued)

\begin{tabular}{|c|c|c|c|c|c|}
\hline DTN & TITLE & TYPE & $\begin{array}{l}\text { STATUS } \\
\text { (start of } \\
\text { review) }\end{array}$ & DISPOSITION & VERIFICATION \\
\hline MO0204RIB00135.000 & $\begin{array}{l}\text { ROCK TENSILE STRENGTH (DIRECT } \\
\text { PULL) }\end{array}$ & $\mathrm{D}$ & $\mathrm{U}$ & $\begin{array}{l}\text { Repeats or } \\
\text { summarizes } \\
\text { values taken from } \\
\text { other sources } \\
\text { that were } \\
\text { evaluated, not } \\
\text { used. }\end{array}$ & $\begin{array}{l}\text { Requires } \\
\text { verification } \\
\text { and/or } \\
\text { qualification. }\end{array}$ \\
\hline MO0204RIB00146.000 & SCHMIDT REBOUND HARDNESS & D & Q & $\begin{array}{l}\text { Repeats or } \\
\text { summarizes } \\
\text { values taken from } \\
\text { other sources } \\
\text { that were } \\
\text { evaluated, not } \\
\text { used. }\end{array}$ & $\begin{array}{l}\text { Requires } \\
\text { verification } \\
\text { and/or } \\
\text { qualification. }\end{array}$ \\
\hline MO0103SEPSMRMP.000 & $\begin{array}{l}\text { SUMMARY OF ROCK MASS } \\
\text { PROPERTIES }\end{array}$ & D & $u$ & $\begin{array}{l}\text { Model } \\
\text { input/output, does } \\
\text { not contain } \\
\text { measured values, } \\
\text { not used. }\end{array}$ & $\begin{array}{l}\text { Requires } \\
\text { verification } \\
\text { and/or } \\
\text { qualification. }\end{array}$ \\
\hline SNF29041993002.031 & $\begin{array}{l}\text { ROCK MASS MECHANICAL } \\
\text { PROPERTIES ESTIMATES FOR } \\
\text { BOREHOLES UE25 NRG-1, NRG-2, } \\
\text { NRG-2A, NRG-3, NRG-4, NRG-5; } \\
\text { USW NRG-6, AND NRG-7/7A } \\
\text { (REVISION 2). }\end{array}$ & D & Q & $\begin{array}{l}\text { No relevant data } \\
\text { presented or out } \\
\text { of area of } \\
\text { interest, not used. }\end{array}$ & $\begin{array}{l}\text { Requires } \\
\text { verification } \\
\text { and/or } \\
\text { qualification. }\end{array}$ \\
\hline SNSAND95048800.000 & $\begin{array}{l}\text { GEOTECHNICAL } \\
\text { CHARACTERIZATION OF THE } \\
\text { NORTH RAMP OF THE } \\
\text { EXPLORATORY STUDIES FACILITY, } \\
\text { VOLUME I: DATA SUMMARY, AND } \\
\text { VOLUME II: NRG BOREHOLE DATA } \\
\text { APPENDICES }\end{array}$ & D & Q & $\begin{array}{l}\text { Repeats or } \\
\text { summarizes } \\
\text { values taken from } \\
\text { other sources } \\
\text { that were } \\
\text { evaluated, not } \\
\text { used. }\end{array}$ & $\begin{array}{l}\text { Requires } \\
\text { verification for } \\
\text { use with } \\
\text { principle factors. }\end{array}$ \\
\hline SNF29041993002.010 & $\begin{array}{l}\text { SCHMIDT HAMMER TEST DATA } \\
\text { FROM NRG DRILL HOLES CORE. }\end{array}$ & A & Q & Directly used & $\begin{array}{l}\text { Requires } \\
\text { verification } \\
\text { and/or } \\
\text { qualification. }\end{array}$ \\
\hline SNF29041993002.024 & $\begin{array}{l}\text { SCHMIDT HAMMER TEST DATA } \\
\text { FROM USW NRG-7/7A DRILL HOLE. }\end{array}$ & A & Q & Directly used & $\begin{array}{l}\text { Requires } \\
\text { verification } \\
\text { and/or } \\
\text { qualification. }\end{array}$ \\
\hline MO0301SETSTTST.000 & $\begin{array}{l}\text { TENSILE STRENGTH TESTING OF } \\
\text { TOPOPAH SPRING TUFF }\end{array}$ & A & $u$ & $\begin{array}{l}\text { Corroborating } \\
\text { (evaluated for } \\
\text { qualification). Not } \\
\text { used, data } \\
\text { remains } \\
\text { unqualified. }\end{array}$ & $\begin{array}{l}\text { Requires } \\
\text { verification } \\
\text { and/or } \\
\text { qualification. }\end{array}$ \\
\hline
\end{tabular}

TYPE Column: $\quad \mathrm{A}=$ Acquired Data; $\mathrm{D}=$ Developed Data; $\mathrm{S}=$ Superseded Data

STATUS Column: $Q=$ Qualified Data; $U=$ Unqualified Data 
Table 2. DTNs That Required Verification in Accordance With AP-3.15Q at Start of the Process

\begin{tabular}{|l|l|}
\hline \multicolumn{1}{|c|}{ DTNs } & \multicolumn{1}{|c|}{ TITLE } \\
\hline GS921283114220.010 & $\begin{array}{l}\text { SPLITTING TENSILE STRENGTH OF INTACT ROCK CORE SPECIMENS FROM UE- } \\
\text { 25 NRG\#1. }\end{array}$ \\
\hline SNL02030193001.002 & $\begin{array}{l}\text { MECHANICAL PROPERTIES DATA FOR DRILL HOLE USW NRG-6 SAMPLES FROM } \\
\text { DEPTH 22.2 FT TO 427.0 FT. }\end{array}$ \\
\hline SNL02030193001.003 & $\begin{array}{l}\text { MECHANICAL PROPERTIES DATA FOR DRILL HOLE UE-25 NRG\#2 SAMPLES } \\
\text { FROM DEPTH 170.4 FT. TO 200.0 FT. }\end{array}$ \\
\hline SNL02030193001.004 & $\begin{array}{l}\text { MECHANICAL PROPERTIES DATA FOR DRILL HOLE USW-NRG-6 SAMPLES FROM } \\
\text { DEPTHS. }\end{array}$ \\
\hline SNL02030193001.005 & $\begin{array}{l}\text { MECHANICAL PROPERTIES DATA FOR DRILL HOLE UE-25 NRG\#3 SAMPLES } \\
\text { FROM DEPTH 15.4 FT. TO 297.1 FT. }\end{array}$ \\
\hline SNL02030193001.006 & $\begin{array}{l}\text { MECHANICAL PROPERTIES DATA FOR DRILL HOLE UE-25 NRG\#2A SAMPLES } \\
\text { FROM DEPTH 90.0 FT. TO 254.5 FT. }\end{array}$ \\
\hline SNL02030193001.009 & $\begin{array}{l}\text { MECHANICAL PROPERTIES DATA FOR DRILL HOLE UE25 NRG-5 SAMPLES FROM } \\
\text { DEPTH 781.0 FT. TO 991.9 FT. }\end{array}$ \\
\hline SNL02030193001.013 & $\begin{array}{l}\text { MECHANICAL PROPERTIES DATA FOR DRILL HOLE UE25 NRG-2B SAMPLES } \\
\text { FROM DEPTH 2.7 FT. TO 87.6 FT. }\end{array}$ \\
\hline SNL02030193001.014 & $\begin{array}{l}\text { MECHANICAL PROPERTIES DATA FOR DRILL HOLE UE25 NRG-4 SAMPLES FROM } \\
\text { DEPTH 378.1 FT. TO 695.8 FT. }\end{array}$ \\
\hline SNL02030193001.017 & $\begin{array}{l}\text { MECHANICAL PROPERTIES DATA FOR DRILLHOLE USW NRG-7/7A SAMPLES } \\
\text { FROM DEPTH 18.0 FT. TO 495.0 FT. }\end{array}$ \\
\hline SNF29041993002.010 & SCHMIDT HAMMER TEST DATA FROM NRG DRILLHOLES CORE. \\
\hline SNF29041993002.024 & SCHMIDT HAMMER TEST DATA FROM USW NRG-7/7A DRILLHOLE. \\
\hline SNL02071596001.001 & $\begin{array}{l}\text { CREEP PROPERTIES OF THE PAINTBRUSH TUFF RECOVERED FROM } \\
\text { BOREHOLE USW NRG-7/7A. }\end{array}$ \\
\hline SOUT: Tab1 1 & \\
\hline
\end{tabular}

Source: Table 1

Table 3. DTNs/Reports Whose Data Will Be Reviewed for Qualification in Accordance With AP-SIII.2Q for Use in the Data Summary DTNs

\begin{tabular}{|l|l|}
\hline \multicolumn{1}{|c|}{ DTN } & \multicolumn{1}{c|}{ DTN/REPORT TITLE } \\
\hline MO0301SETSTTST.000 & TENSILE STRENGTH TESTING OF TOPOPAH SPRING TUFF \\
\hline SNL02040687004.001 & CREEP IN TOPOPAH SPRING MEMBER WELDED TUFF (Martin et al. 1995) \\
\hline
\end{tabular}

Source: Table 1 
Table 4. DTNs That Will Supply Qualified and Verified Data for the Data Summary DTNs

\begin{tabular}{|c|c|}
\hline DTN & TITLE \\
\hline GS921283114220.010 & $\begin{array}{l}\text { SPLITTING TENSILE STRENGTH OF INTACT ROCK CORE SPECIMENS FROM UE- } \\
25 \text { NRG\#1. }\end{array}$ \\
\hline SNL02030193001.002 & $\begin{array}{l}\text { MECHANICAL PROPERTIES DATA FOR DRILLHOLE USW NRG-6 SAMPLES FROM } \\
\text { DEPTH 22.2 FT TO } 427.0 \mathrm{FT} \text {. }\end{array}$ \\
\hline SNL02030193001.003 & $\begin{array}{l}\text { MECHANICAL PROPERTIES DATA FOR DRILLHOLE UE-25NRG\#2 SAMPLES FROM } \\
\text { DEPTH } 170.4 \text { FT. TO } 200.0 \mathrm{FT} \text {. }\end{array}$ \\
\hline SNL02030193001.004 & $\begin{array}{l}\text { MECHANICAL PROPERTIES DATA FORDRILLHOLE USW-NRG-6 SAMPLES FROM } \\
\text { DEPTH } 462.3 \mathrm{FT} \text {. TO } 1085.0 \mathrm{FT} \text {. }\end{array}$ \\
\hline SNL02030193001.005 & $\begin{array}{l}\text { MECHANICAL PROPERTIES DATA FOR DRILLHOLE UE-25NRG\#3 SAMPLES FROM } \\
\text { DEPTH 15.4 FT. TO 297.1 FT. }\end{array}$ \\
\hline SNL02030193001.006 & $\begin{array}{l}\text { MECHANICAL PROPERTIES DATA FOR DRILL HOLE UE-25NRG\#2A SAMPLES } \\
\text { FROM DEPTH } 90.0 \mathrm{FT} \text {. TO } 254.5 \mathrm{FT} \text {. }\end{array}$ \\
\hline SNL02030193001.009 & $\begin{array}{l}\text { MECHANICAL PROPERTIES DATA FOR DRILLHOLE UE25 NRG-5 SAMPLES FROM } \\
\text { DEPTH } 781.0 \text { FT. TO 991.9 FT. }\end{array}$ \\
\hline SNL02030193001.013 & $\begin{array}{l}\text { MECHANICAL PROPERTIES DATA FOR DRILLHOLE UE25 NRG-2B SAMPLES } \\
\text { FROM DEPTH 2.7 FT. TO 87.6 FT. }\end{array}$ \\
\hline SNL02030193001.014 & $\begin{array}{l}\text { MECHANICAL PROPERTIES DATA FOR DRILLHOLE UE25 NRG-4 SAMPLES FROM } \\
\text { DEPTH } 378.1 \mathrm{FT} \text {. TO } 695.8 \mathrm{FT} \text {. }\end{array}$ \\
\hline SNL02030193001.017 & MECHANICAL PROPERTIES DATA FOR DRILL HOLE USW NRG-7/7A SAMPLES \\
\hline SNL02030193001.019 & $\begin{array}{l}\text { MECHANICAL PROPERTIES DATA FOR DRILLHOLE USW NRG-7/7A SAMPLES } \\
\text { FROM DEPTH 507.4 FT. TO 881.0 FT. }\end{array}$ \\
\hline SNL02030193001.020 & $\begin{array}{l}\text { MECHANICAL PROPERTIES DATA FOR DRILLHOLE USW NRG-7/7A SAMPLES } \\
\text { FROM DEPTH 554.7 FT. TO 1450.1 FT. }\end{array}$ \\
\hline SNF29041993002.010 & SCHMIDT HAMMER TEST DATA FROM NRG DRILL HOLES CORE. \\
\hline SNF29041993002.024 & SCHMIDT HAMMER TEST DATA FROM USW NRG-7/7A DRILL HOLE \\
\hline SNL02071596001.001 & $\begin{array}{l}\text { CREEP PROPERTIES OF THE PAINTBRUSH TUFF RECOVERED FROM } \\
\text { BOREHOLE USW NRG-7/7A. }\end{array}$ \\
\hline
\end{tabular}

Source: Table 1 
Table 5. Summary of Qualified Test Results for Brazil Tensile Strength Data by Lithostratigraphic Unit

\begin{tabular}{|c|c|c|c|c|c|c|c|}
\hline Formation & $\begin{array}{c}\text { Lithostratigraphic } \\
\text { Unit }\end{array}$ & $\begin{array}{l}\text { Number } \\
\text { of Tests }\end{array}$ & $\begin{array}{c}\text { Mean Value } \\
(\mathrm{MPa})\end{array}$ & $\begin{array}{c}\text { Standard } \\
\text { Deviation } \\
\text { (MPa) }\end{array}$ & $\begin{array}{c}\text { Median } \\
\text { Value } \\
(\mathrm{MPa})\end{array}$ & $\begin{array}{c}\text { Minimum } \\
\text { Value } \\
\text { (MPa) } \\
\end{array}$ & $\begin{array}{c}\text { Maximum } \\
\text { Value (MPa) }\end{array}$ \\
\hline Rainier Mesa Tuff & $\mathrm{Tmr}$ & 3 & 1.23 & 1.27 & 0.60 & 0.40 & 2.70 \\
\hline Tuff Unit " $x$ " & Tpki & 6 & 0.70 & 0.24 & 0.70 & 0.40 & 1.00 \\
\hline \multirow{8}{*}{ Tiva Canyon Tuff } & Tpcrv & 1 & 8.70 & - & 8.70 & 8.70 & 8.70 \\
\hline & Tpcrn & 16 & 7.75 & 3.40 & 8.32 & 2.70 & 13.44 \\
\hline & Tpcpul & 19 & 10.07 & 1.81 & 10.00 & 6.23 & 13.58 \\
\hline & Tpcpmn & 13 & 15.50 & 3.01 & 15.70 & 7.20 & 18.90 \\
\hline & Tpcplnh & 25 & 8.96 & 3.42 & 9.60 & 2.60 & 14.80 \\
\hline & Tpcplnc & 8 & 11.29 & 1.70 & 11.55 & 8.20 & 13.40 \\
\hline & Tpcpv2 & 3 & 3.60 & 2.10 & 4.50 & 1.20 & 5.10 \\
\hline & Tpcpv1 & 3 & 3.27 & 3.65 & 1.90 & 0.50 & 7.40 \\
\hline \multirow{2}{*}{ Yucca Mountain Tuff } & Tpy & 1 & 3.00 & - & 3.00 & 3.00 & 3.00 \\
\hline & Tpbt3 & 2 & 0.20 & 0.14 & 0.20 & 0.10 & 0.30 \\
\hline \multirow{2}{*}{ Pah Canyon Tuff } & Tpp & 12 & 0.19 & 0.19 & 0.15 & 0.02 & 0.70 \\
\hline & Tpbt2 & 5 & 0.30 & 0.29 & 0.20 & 0.10 & 0.80 \\
\hline \multirow{7}{*}{ Topopah Spring Tuff } & Tptrn & 53 & 5.49 & 2.09 & 5.10 & 1.60 & 10.50 \\
\hline & Tptrl & 7 & 4.81 & 1.36 & 5.10 & 3.40 & 7.30 \\
\hline & Tptpul & 19 & 5.57 & 3.10 & 4.30 & 1.90 & 12.90 \\
\hline & Tptpmn & 14 & 10.88 & 4.02 & 12.05 & 4.30 & 16.80 \\
\hline & Tptpll & 24 & 8.33 & 2.93 & 8.25 & 3.20 & 14.30 \\
\hline & Tptpln & 13 & 7.92 & 2.55 & 7.60 & 4.80 & 13.70 \\
\hline & Tptpv3 & 3 & 3.97 & 0.32 & 4.10 & 3.60 & 4.20 \\
\hline
\end{tabular}

Source: DTN MO0306DQRIRPTS.002

Table 6. Summary of Test Results for Unqualified Tensile Strength Data by Lithostratigraphic Unit

\begin{tabular}{|l|c|l|c|c|c|c|c|c|}
\hline Formation & $\begin{array}{c}\text { Lithostratigraphic } \\
\text { Unit }\end{array}$ & Test Type & $\begin{array}{c}\text { Number } \\
\text { of Tests }\end{array}$ & $\begin{array}{c}\text { Mean } \\
\text { Value } \\
(\mathbf{M P a})\end{array}$ & $\begin{array}{c}\text { Standard } \\
\text { Deviation }\end{array}$ & $\begin{array}{c}\text { Median } \\
\text { Value } \\
\text { (MPa) }\end{array}$ & $\begin{array}{c}\text { Minimum } \\
\text { Value } \\
\text { (MPa) }\end{array}$ & $\begin{array}{c}\text { Maximum } \\
\text { Value } \\
\text { (MPa) }\end{array}$ \\
\hline \multirow{2}{*}{$\begin{array}{l}\text { Topopah } \\
\text { Spring Tuff }\end{array}$} & \multirow{3}{*}{ Tptpmn } & All & 22 & 13.88 & 8.60 & 13.77 & 1.94 & 26.26 \\
\cline { 3 - 10 } & Direct-Pull & 11 & 6.07 & 3.09 & 6.19 & 1.94 & 11.53 \\
\cline { 3 - 9 } & & $\begin{array}{l}\text { Brazil } \\
\text { Tests }\end{array}$ & 11 & 21.69 & 3.39 & 22.33 & 16.01 & 26.26 \\
\hline
\end{tabular}

Source: DTN: MO0301SETSTTST.000 
Table 7. Summary of Test Results for Schmidt Hammer Rebound Hardness Values by Lithostratigraphic Unit

\begin{tabular}{|c|c|c|c|c|c|c|c|}
\hline Formation & $\begin{array}{c}\text { Lithostratigraphic } \\
\text { Unit }\end{array}$ & $\begin{array}{l}\text { Number } \\
\text { of Tests }\end{array}$ & $\begin{array}{l}\text { Mean } \\
\text { Value }\end{array}$ & $\begin{array}{l}\text { Standard } \\
\text { Deviation }\end{array}$ & $\begin{array}{l}\text { Median } \\
\text { Value }\end{array}$ & $\underset{\text { Value }}{\text { Minimum }}$ & $\begin{array}{l}\text { Maximum } \\
\text { Value }\end{array}$ \\
\hline Rainier Mesa Tuff & (Tmr) & 4 & 35.10 & 19.60 & 34.20 & 17.10 & 55.10 \\
\hline \multirow{10}{*}{ Tiva Canyon Tuff } & Tpcrv & 2 & 33.80 & 14.28 & 33.80 & 23.70 & 43.90 \\
\hline & Tpcrn & 13 & 26.39 & 11.76 & 22.30 & 11.20 & 48.50 \\
\hline & Tpcpul & 4 & 48.13 & 4.15 & 47.80 & 43.80 & 53.10 \\
\hline & Tpcpmn & 5 & 45.64 & 4.26 & 47.70 & 39.20 & 49.00 \\
\hline & Tpcpll & 5 & 52.92 & 5.51 & 51.20 & 47.20 & 58.90 \\
\hline & Tpcplnh & 6 & 47.17 & 1.68 & 47.10 & 44.70 & 49.90 \\
\hline & Tpcplnc & 9 & 46.69 & 3.46 & 46.80 & 40.20 & 51.90 \\
\hline & Tpcpv3 & 13 & 46.78 & 3.13 & 47.20 & 38.40 & 50.60 \\
\hline & Tpcpv2 & 2 & 41.10 & 6.79 & 41.10 & 36.30 & 45.90 \\
\hline & Tpcpv1 & 1 & 34.20 & - & 34.20 & 34.20 & 34.20 \\
\hline \multirow{2}{*}{ Pah Canyon Tuff } & Tpp & 1 & 19.50 & - & 19.50 & 19.50 & 19.50 \\
\hline & Tpbt2 & 1 & 16.10 & - & 16.10 & 16.10 & 16.10 \\
\hline \multirow{7}{*}{ Topopah Spring Tuff } & Tptrv & 1 & 36.50 & - & 36.50 & 36.50 & 36.50 \\
\hline & Tptrn & 33 & 49.72 & 4.68 & 49.30 & 41.97 & 58.95 \\
\hline & Tptrl & 6 & 48.33 & 3.89 & 48.51 & 42.40 & 53.50 \\
\hline & Tptpul & 19 & 47.93 & 8.84 & 51.06 & 27.30 & 56.75 \\
\hline & Tptpmn & 25 & 42.52 & 13.11 & 48.01 & 11.70 & 58.57 \\
\hline & Tptpll & 12 & 49.35 & 8.87 & 50.55 & 24.30 & 58.00 \\
\hline & Tptpln & 6 & 46.23 & 2.79 & 45.84 & 43.43 & 49.42 \\
\hline
\end{tabular}

Source: DTN MO0306DQRIRPSH.001 
Table 8. Summary of Test Results for Seismic Velocity Values Measured for Creep Calculations

\begin{tabular}{|c|c|c|c|c|c|c|}
\hline Sample Number & $\begin{array}{l}\text { Compressive } \\
\text { Stress (MPa) }\end{array}$ & $\begin{array}{c}\text { Compression } \\
\text { Wave } \\
\text { Velocity }(\mathrm{Km} / \mathrm{s})\end{array}$ & $\begin{array}{c}\text { Orthogonal } \\
\text { polarized shear } \\
\text { wave } \mathbf{S 1} \text { Velocity } \\
(\mathrm{Km} / \mathrm{s})\end{array}$ & $\begin{array}{c}\text { Orthogonal } \\
\text { polarized shear } \\
\text { wave S2 } \\
\text { Velocity }(\mathrm{Km} / \mathrm{s})\end{array}$ & $\begin{array}{c}\text { Radial } \\
\text { Polarized } \\
\text { Compression } \\
\text { Wave } \\
\text { Velocity }(\mathrm{Km} / \mathrm{s})\end{array}$ & $\begin{array}{c}\text { Radial } \\
\text { polarized } \\
\text { shear wave } \\
\text { Velocity }(\mathrm{Km} / \mathrm{s})\end{array}$ \\
\hline $\begin{array}{l}\text { NRG-7/7A- } \\
\text { 776.6-SNL }\end{array}$ & 70 & 4.357 & 2.774 & 2.730 & 4.388 & 2.808 \\
\hline $\begin{array}{l}\text { NRG-7/7A- } \\
807.6-S N L\end{array}$ & 40 & 4.426 & 2.775 & 2.712 & 4.418 & 2.836 \\
\hline $\begin{array}{l}\text { NRG-7/7A- } \\
\text { 808.3-SNL }\end{array}$ & 129 & 4.455 & 2.800 & 2.848 & 4.471 & 2.824 \\
\hline $\begin{array}{l}\text { NRG-7/7A- } \\
858.4-S N L \\
\end{array}$ & 100 & 4.488 & 2.816 & 2.769 & 4.465 & 2.847 \\
\hline $\begin{array}{l}\text { NRG-7/7A- } \\
\text { 1264.5-SNL } \\
\end{array}$ & 98 & 4.064 & 2.563 & 2.510 & 4.450 & 2.703 \\
\hline $\begin{array}{l}\text { NRG-7/7A- } \\
1281.4-S N L\end{array}$ & 132 & 4.431 & $\mathrm{~N} / \mathrm{A}$ & $\mathrm{N} / \mathrm{A}$ & 4.618 & 2.815 \\
\hline
\end{tabular}

Source: DTN MO0306DQRIRPTC.001

Table 9. Summary of Test Results for Maximum Axial Strain Calculated for Creep Calculations

\begin{tabular}{|l|c|c|c|c|c|c|c|}
\hline Sample Number & $\begin{array}{c}\text { Strain at } \\
\mathbf{1 , 0 0 0 s} \\
\text { (millistrain) }\end{array}$ & $\begin{array}{c}\text { Strain at } \\
\text { termination } \\
\text { (millistrain) }\end{array}$ & $\begin{array}{c}\text { Stress } \\
\text { Difference } \\
\text { (MPa) }\end{array}$ & $\begin{array}{c}\text { Lithostratigraphic } \\
\text { Unit }\end{array}$ & $\begin{array}{c}\text { Sample } \\
\text { Diameter } \\
\text { (mm) }\end{array}$ & $\begin{array}{c}\text { Sample } \\
\text { Length } \\
\text { (mm) }\end{array}$ & $\begin{array}{c}\text { Cumulative Test } \\
\text { Duration (days) }\end{array}$ \\
\hline $\begin{array}{l}\text { NRG-7/7A-776.6- } \\
\text { SNL }\end{array}$ & 2.34 & 2.52 & 70 & Tptpmn & 50.8 & 101.6 & 43.5 \\
\hline $\begin{array}{l}\text { NRG-7/7A-807.6- } \\
\text { SNL }\end{array}$ & 1.08 & 1.16 & 40 & Tptpmn & 50.8 & 101.6 & 43.5 \\
\hline $\begin{array}{l}\text { NRG-7/7A-808.3- } \\
\text { SNL }\end{array}$ & 3.02 & 3.06 & 129 & Tptpmn & 50.8 & 101.6 & 68.3 \\
\hline $\begin{array}{l}\text { NRG-7/7A-858.4- } \\
\text { SNL }\end{array}$ & 2.69 & 2.88 & 100 & Tptpmn & 50.8 & 101.6 & 43.5 \\
\hline $\begin{array}{l}\text { NRG-7/7A-1264.5- } \\
\text { SNL }\end{array}$ & 3.01 & 3.25 & 98 & Tptpln & 50.8 & 101.6 & 29.5 \\
\hline $\begin{array}{l}\text { NRG-7/7A-1281.4- } \\
\text { SNL }\end{array}$ & 3.70 & 4.04 & 132 & Tptpln & 50.8 & 101.6 & 29.5 \\
\hline $\begin{array}{l}\text { NRG-7/7A-1400.5- } \\
\text { SNL }\end{array}$ & 3.47 & 3.84 & 131 & Tptpln & 50.8 & 101.6 & 29.5 \\
\hline
\end{tabular}

Source: DTN: MO0306DQRIRPTC.001 
Table 10. Available Documentation for Unqualified Sources

\begin{tabular}{|l|l|l|}
\hline \multicolumn{1}{|c|}{ DTN/Report } & \multicolumn{1}{|c|}{ Accession/Package Number } & \multicolumn{1}{c|}{ Contents } \\
\hline \multirow{4}{*}{ MO0301SETSTTST.000 } & MOY-030716-14-01 & $\begin{array}{l}\text { Record Package for data } \\
\text { submittal }\end{array}$ \\
\cline { 2 - 3 } & NNA.19910322.0056 & Report SAND91-0044 \\
\cline { 2 - 3 } & MOY-910808-03-04 & $\begin{array}{l}\text { Record Package for report } \\
\text { SAND91-0044 }\end{array}$ \\
\hline \multirow{5}{*}{ Martin et al. 1995 } & MOL.19950502.0006 & Report SAND94-2585 \\
\cline { 2 - 3 } & MOY-950831-19-03 & $\begin{array}{l}\text { Record Package for SAND94- } \\
\text { 2585 including draft, } \\
\text { correspondence, and review } \\
\text { documents }\end{array}$ \\
\cline { 2 - 3 } & MOY-980803-05-02 & $\begin{array}{l}\text { Record package for SAND94- } \\
\text { 2585 including report and review } \\
\text { documents }\end{array}$ \\
\cline { 2 - 3 } & MOY-030304-05-03 & $\begin{array}{l}\text { Report and work agreement for } \\
\text { SAND94-2585 }\end{array}$ \\
\hline
\end{tabular}


INTENTIONALLY LEFT BLANK 


\section{ATTACHMENT I \\ STRATIGRAPHIC COLUMN AND SYMBOLS USED IN REPORT}




\section{INTENTIONALLY LEFT BLANK}


Table I-1. Stratigraphic Column and Symbols Used in Report

\begin{tabular}{|c|c|c|c|c|}
\hline Definition/Name & Group & Formation & Member & Zone \\
\hline Timber Mountain Group & $\mathrm{Tm}$ & & & \\
\hline Rainier Mesa Tuff & & Tmr & & \\
\hline Paintbrush Group & $\mathrm{Tp}$ & & & \\
\hline Post tuff unit "x" bedded tuff & & & Tpbt6 & \\
\hline Tuff unit "x" & & & $\begin{array}{l}\text { Tpki } \\
\text { (informal) }\end{array}$ & \\
\hline Pre-tuff unit "x" bedded tuff & & & Tpbt5 & \\
\hline Tiva Canyon Tuff & & Tpc & & \\
\hline Crystal-Rich Member & & & Tpcr & \\
\hline Vitric zone & & & & Tpcrv \\
\hline Nonlithophysal zone & & & & Tpcrn \\
\hline Lithophysal zone & & & & Tpcrl \\
\hline Crystal-Poor Member & & & Tpсp & \\
\hline Upper lithophysal zone & & & & Tpcpul \\
\hline Middle nonlithophysal zone & & & & Tpcpmn \\
\hline Lower lithophysal zone & & & & Tpcpll \\
\hline Lower nonlithophysal zone & & & & Tpcpln \\
\hline Vitric zone & & & & Tpcpv \\
\hline Pre-Tiva Canyon bedded tuff & & & Tpbt4 & \\
\hline Yucca Mountain Tuff & & Tpy & & \\
\hline Pre-Yucca Mountain bedded tuff & & & Tpbt3 & \\
\hline Pah Canyon Tuff & & Tpp & & \\
\hline Pre-Pah Canyon bedded tuff & & & Tpbt2 & \\
\hline Topopah Spring Tuff & & Tpt & & \\
\hline Crystal-Rich Member & & & Tptr & \\
\hline Vitric zone & & & & Tptrv \\
\hline Nonlithophysal zone & & & & Tptrn \\
\hline Lithophysal zone & & & & Tptrl \\
\hline
\end{tabular}


Table I-1. Stratigraphic Column and Symbols Used in Report (Continued)

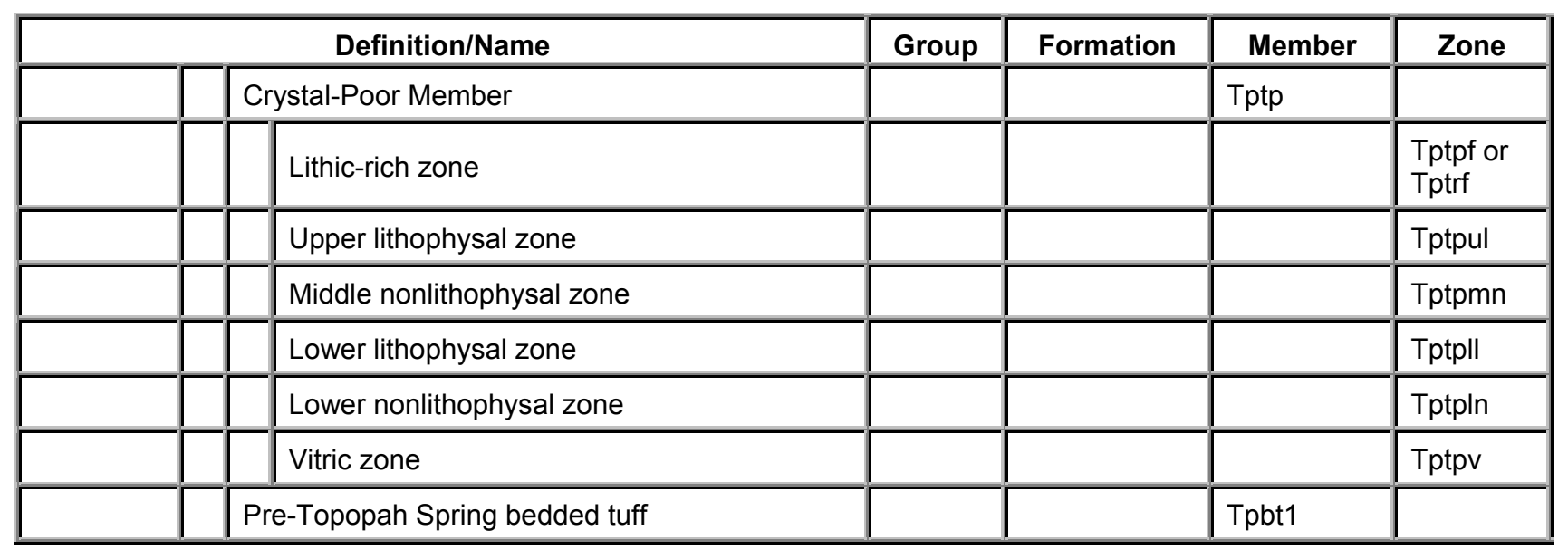

Source: MO0004QGFMPICK.000 